\title{
ANATOMÍA DE UN PRÉSTAMO PARA LA GUERRA DE GRANADA: DINÁMICAS COOPERATIVAS Y NEGOCIACIÓN EN TORNO A LA COMPRA DE MAQUEDA POR GUTIERRE de CÁrdenas y el empréstito de Alonso Carrillo DE ACUÑA (1483-1491)
}

\author{
Pablo Ortego Rico ${ }^{1}$ \\ Universidad de Málaga \\ Manuel García Fernández ${ }^{2}$ \\ Universidad de Sevilla
}

Recibido: 11 de mayo de 2020

Aceptado: 24 de agosto de 2020

\begin{abstract}
Resumen
La compra de la villa de Maqueda por Gutierre de Cárdenas, contador mayor de los Reyes Católicos, en 1483 a Alonso Carrillo de Acuña, guarda mayor, estuvo relacionada hasta 1491 con la prolija negociación de un importante préstamo regio de dieciséis millones de maravedís para la Guerra de Granada. El análisis de la documentación conservada al respecto nos descubre el complicado proceso de financiación, ejecución, amortización y cancelación del mismo con sus intermediarios financieros, así como las medidas tendentes a maximizar sus posibles beneficios. Así mismo el estudio comparado de las fuentes hacendísticas relacionadas con el préstamo de Carrillo a la Corona nos proporciona información sobre la deuda pública en la hacienda regia castellana del siglo XV.
\end{abstract}

\section{Palabras clave}

Préstamos, hacienda regia, negociación, señoríos, Guerra de Granada.

\footnotetext{
Abstract

The purchase of the town of Maqueda in 1483 by Gutierre de Cárdenas, chief accountant of the Catholic Monarchs, from Alonso Carrillo de Acuña, senior guard, was related, until 1491, to the prolix negotiation of an important royal loan of sixteen million maravedís for the War of Granada. The analysis of the documentation preserved on this subject reveals the complicated process of fi-

1 Departamento de Ciencias Históricas. Universidad de Málaga. Correo electrónico: portego@uma.es. ORCID: https://orcid.org/0000-0002-1780-4633.

2 Departamento de Historia Medieval y Ciencias y Técnicas Historiográficas. Universidad de Sevilla. Correo electrónico: manuelgf@us.es. ORCID: https://orcid.org/0000-0001-9116-5510.
} 
nancing, execution, repayment and cancellation of the loan with its financial intermediaries, as well as the measures to maximize its possible benefits. Likewise, the comparative study of the tax sources related to Carrillo's loan to the Crown provides us information about the public debt in the 15th century Castilian royal estate.

\section{Keywords}

Loans, royal treasury, negotiation, manors, Granada War.

\section{Resumo}

A compra da cidade de Maqueda por Gutierre de Cárdenas, Contador-mor dos Reis Católicos, a Alonso Carrillo de Acuña, Guarda-mor, em 1483 esteve relacionado até 1491 com a longa e complexa negociação de um importante empréstimo régio de dezasseis milhões de maravedis para a Guerra de Granada. A análise da documentação preservada a esse respeito revela-nos o complicado processo de financiamento, execução, amortização e cancelamento do mesmo com seus intermediários financeiros, bem como as medidas destinadas a potenciar os seus possíveis benefícios. Da mesma forma, o estudo comparativo das fontes de financiamento relacionadas com o empréstimo de Carrillo à Coroa, fornece-nos informações sobre a dívida pública no patrimônio régio castelhano do século XV.

\section{Palavras-chave}

Empréstimos, tesouro real, negociação, senhorios, Guerra de Granada.

\section{Introducción: Carrillo y Cárdenas ${ }^{3}$}

Hace ya varias décadas que el profesor Ladero Quesada dio a conocer un interesante préstamo de 16.000.000 mrs que el guarda mayor del rey Alonso Carrillo de Acuña, alcalde mayor de la ciudad de Toledo y sobrino del arzobispo de Toledo homónimo fallecido en 1482, otorgó a los Reyes Católicos en 1483 para sufragar los gastos de las campañas iniciales de la guerra de conquista de Granada ${ }^{4}$. La importancia de la operación reside en dos particularidades que la singularizan de otros préstamos coetáneos destinados a financiar los gastos generados por la contienda. En primer lugar, se trata del mayor empréstito negociado en una única operación entre 1483 y 1492 que se conoce, cuya cuantía excede los préstamos por encima de los 10.000.000 mrs abonados

\footnotetext{
Este trabajo forma parte de los siguientes Proyectos de Investigación: "La construcción de una cultura fiscal en Castilla: poderes, negociación y articulación social (ca. 1250-1550)" (PGC2018-097738-B-100), "Circuitos financieros, crecimiento económico y guerra (siglos XV-XVI)" (UMA18-FEDERJA-098) y "Expresiones de la cultura política peninsular en las relaciones de conflicto (Corona de Castilla, 12301504)" (HAR2016-76174-P), integrados en la Red Arca Comunis (http://www.arcacomunis.uma.es). Siglas y abreviaturas empleadas: AGS = Archivo General de Simancas; AHN = Archivo Histórico Nacional; AHNob. $=$ Archivo Histórico de la Nobleza; AFRM = Archivo Francisco Rodríguez Marín (Biblioteca Tomás Navarro del CSIC de Madrid); CMC 1 ép. = Contaduría Mayor de Cuentas, Primera Época; doc.= documento; EH $=$ Expedientes de Hacienda; EMR = Escribanía Mayor de Rentas; f./ff. = folio/s; mrs = maravedíes; leg. = legajo; RGS = Registro General del Sello.

4 Ladero Quesada, Castilla y la conquista del reino de Granada, pp. 216, 218 y 299. LAdERo Quesada, La Hacienda Real de Castilla, 1369-1504, p. 226.
} 
por instituciones como la Mesta, ciudades como Valencia, importantes miembros de la alta nobleza como el duque de Medina Sidonia y el marqués de Cádiz, y otros agentes como el escribano de ración Luis de Santángel o Diego de Acevedo5.

Por otra parte, en términos cualitativos, se trataba de una operación compleja, que dio lugar a negociaciones desarrolladas a lo largo de varios años, en la cual la Corona recurrió a mecanismos de amortización diferentes a la mera devolución de los fondos anticipados con cargo a otras rentas extraordinarias de titularidad regia, como el dinero procedente del subsidio eclesiástico y de la bula de cruzada, utilizado con profusión a partir de 1484 en las operaciones de reintegro de capitales adelantados por instituciones y particulares ${ }^{6}$. Además, es bien conocido el vínculo de este préstamo con la venta de la villa de Maqueda el mismo año (1483) realizada por Alonso Carrillo a Gutierre de Cárdenas, Comendador Mayor de León, contador mayor de los reyes y uno de sus principales colaboradores políticos desde su etapa como príncipes, cuya intervención resultaría clave para capitalizar una cuantía tan elevada?.

Sobre ambos personajes, cuyas biografías se cruzaron a finales del siglo XV en torno al señorío y la propiedad de la villa de Maqueda, estamos relativamente bien informados ${ }^{8}$. No obstante, para la correcta exégesis de las circunstancias en las cuales se produjo la adquisición de la villa por Gutierre de Cárdenas, y el préstamo entregado por Alonso Carrillo a los Reyes Católicos, son imprescindibles los documentos -en su mayor parte inéditos o de difícil localización- conservados en el Fondo "Archivo Francisco Rodríguez Marín” de la Biblioteca Tomás Navarro Tomás del Consejo Superior de Investigaciones Científicas de Madrid, cuyo regesto se dio a conocer hace algunos años situándolo en

\footnotetext{
5 Véanse por ejemplo los préstamos concedidos por la Mesta (10.000.000 mrs en 1483), ciudades como Valencia (15.900.000 mrs en 1489), el duque de Medina Sidonia (10.000.000 mrs en 1489), el duque de Cádiz (10.000.000 mrs en 1491) y otros agentes (10.000.000 mrs entregados por Diego de Acevedo en 1989 o el préstamo de 10.196 .300 mrs realizado por el escribano de ración Luis de Santángel en 1491). Ladero Quesada, Castilla y la conquista, pp. 293-299. Sobre los dos préstamos que el marqués, luego duque, de Cádiz, señor de Marchena y conde de Arcos Rodrigo Ponce de León concedió quizás en 1487 y 1489 a los reyes para la guerra ver CAÑAS Gálvez, "Fray Hernando de Talavera", pp. 175-196.

6 Sobre el papel de la cruzada en la devolución de préstamos ver Ladero Quesada, La Hacienda Real de Castilla, 1369-1504, p. 229-241. Ortego Rico, "Castilla, la Corona de Aragón y el Papado", pp. 199-248.

7 Ladero Quesada, La Hacienda Real de Castilla, 1369-1504, pp. 226 y 338.

8 Franco Silva adelantó hace ya algunos años numerosos aspectos políticos, sociales y patrimoniales del linaje Carrillo-Acuña, señores de Caracena, en la tierra de Soria, a finales del siglo XV y comienzos del siglo XVI, que siguen siendo de obligada referencia para analizar la figura de Alfonso Carrillo de Acuña. Franco Silva, La fortuna y el poder, pp. 217-238. Resulta también de interés el trabajo más reciente de A. Quijorna Rodríguez sobre las estrategias de promoción social utilizadas por el linaje. QuiJorna RodríGuEz, "Mecanismos y estrategias de promoción", pp. 215-237. Por su parte, para Gutierre de Cárdenas la información es más abundante, gracias al trabajo de M. C. Quintanilla Raso y F. Blázquez Mayoral sobre la génesis, formación y evolución patrimonial de la Casa Ducal de Maqueda, que actualiza la bibliografía y los conocimientos referentes al Comendador Mayor de León, su linaje, papel político, proyección social y económica, y su patrimonio señorial desde 1440 a 1541 . Quintanilla Raso y BlázQuez Mayoral, $L a$ forja de una casa nobiliaria. Son igualmente de interés los trabajos de Manuel Espinar Moreno sobre Cárdenas en la línea de investigación patrimonial y nobiliaria señalada. EsPINAR MoRENo, Noticias sobre la Historia de Elche II y Testamento de don Gutierre de Cárdenas.
} 
su contexto histórico y heurístico", combinados con las cuentas y registros simanquinos. Entre estos documentos se encuentra el original de la carta de pago, fechada en Vitoria el 10 de octubre de $1483^{10}$, según la cual, en representación de los reyes, fray Hernando de Talavera reconocía haber recibido de Cárdenas y de otras personas en su nombre 16.000.000 mrs que Alonso Carrillo de Acuña se había comprometido a entregar en préstamo a los monarcas para sufragar los gastos de la guerra de Granada, procedentes de los 17.150.000 mrs por los cuales este último había vendido a Cárdenas su villa de Maqueda con todos sus derechos, propiedades y aldeas, según carta de pago expedida el 21 de febrero de $1483^{11}$.

Sin embargo, la definitiva adquisición de Maqueda por el Comendador Mayor de León, como nuevo centro identitario del linaje en el territorio castellano y germen del futuro Ducado que ostentaría, no fue una empresa fácil. Pese a que los primeros contactos con su propietario se iniciaron antes de octubre de 1479, Alonso Carrillo dilató la transacción, quizás con la intención de obtener un precio más elevado por su cesión a Cárdenas, mediante una estrategia de la que formaron parte ventas fingidas y requerimientos mutuos con su hijo Gómez Carrillo, denunciadas por el Comendador Mayor en un proceso remitido al Consejo Real en octubre de 1480. La venta de Maqueda por 17.150.000 mrs se formalizó definitivamente en Madrid el 3 de febrero de $1483^{12}$, tras la renuncia de Gómez Carrillo a sus derechos sobre el señorío. Sin embargo, nuevas dificultades obstaculizaron su posesión plena por Cárdenas hasta 1490, alcanzada finalmente gracias a la intervención de los reyes ${ }^{13}$.

\section{Capitalización y pago del préstamo de Alonso Carrillo: ¿un juego "de suma positiva"?}

Al margen de los problemas derivados de la toma de posesión del señorío, la documentación que generó la compra de Maqueda por Gutierre de Cárdenas y el préstamo de Alonso Carrillo permite comprender mejor los mecanismos, algunos de ellos novedosos o poco utilizados hasta ese momento, de los que se sirvió la Corona para obtener dinero líquido con el cual hacer frente a los gastos iniciales de una guerra de conquista, como la de Granada, que planteó retos hacendísticos inéditos y a cuyo servicio se pusieron

\footnotetext{
9 García Fernández, "La documentación medieval". En este artículo se analiza detalladamente la gestación y ordenación archivística de este curioso fondo documental, en su mayor parte inédito, organizado para su uso particular y exclusivo por Francisco Rodríguez Marín, director que fue de la Biblioteca Nacional y de la Real Academia de la Historia, en las primeras décadas del siglo pasado hasta su muerte en 1943. Tras su fallecimiento pasaron al CSIC. En el mismo se regesta una interesante colección documental bajomedieval (1434-1558) relacionada en su mayor parte con la formación patrimonial de la Casa Ducal de Maqueda y otras propiedades de su señorío en el reino de Castilla y en la Corona de Aragón.

10 AFRM, Caja, 98, leg. 1, doc. 15. García FernÁndez, "La documentación medieval", p. 192.

AFRM, Caja 98, leg. 1, doc. 14 (a).

AFRM, Caja 98, leg. 1, doc. 32.

13 Quintanilla Raso y BlázQuez Mayoral, La forja de una casa nobiliaria, pp. 173-181.
} 
desde el primer momento buena parte de los recursos del aparato estatal y del reino ${ }^{14}$. En este sentido, la documentación conservada ofrece una "anatomía" completa de la capitalización, pago y amortización de un importante préstamo que -junto a otros semejantes, aunque de menor cuantía- pudo impulsar y sostener las primeras operaciones militares lanzadas contra el emirato nazarí.

Ello permite aproximarse "desde dentro" a mecanismos financieros generadores de deuda cada vez mejor conocidos para la Castilla de esta época gracias a los avances experimentados por la investigación ${ }^{15}$, pero también a dinámicas de negociación que respondían a los intereses de diversas partes. Estos intereses convergían, en el caso aquí presentado, en torno a una operación financiera que podría caracterizarse desde el punto de vista teórico como un juego de suma "distinta de cero" o de "suma positiva" en la medida en que las ganancias derivadas de las estrategias aplicadas por aquellos agentes que interaccionaban entre sí - en este caso la Corona, Gutierre de Cárdenas y Alonso Carrillo - no se correspondían con las pérdidas de los otros participantes. Es decir, cada uno de ellos buscaba racionalizar su toma de decisiones con la finalidad de terminar en una posición mejor a la que tenía antes de producirse la negociación ${ }^{16}$. En el contexto de la época, disponer de señoríos y percibir rentas a perpetuidad eran beneficios de la máxima relevancia para consolidar/acrecentar la posición política y el rango social, y es ahí de donde parte la estrategia seguida por la Corona en el caso de Gutierre de Cárdenas y Alonso Carrillo de Acuña en su búsqueda de recursos para financiar la guerra de Granada canalizados mediante un instrumento poco utilizado hasta esta época por parte de la Real Hacienda: la venta de jurisdicciones señoriales.

\subsection{La venta de jurisdicciones como mecanismo de capitalización de préstamos}

El papel asignado a Gutierre de Cárdenas en la financiación de la guerra de Granada ya aparece recogido en los primeros proyectos redactados para aconsejar a los reyes sobre los posibles mecanismos que se podrían destinar para obtener recursos económicos. El memorial del llamado "fraile blanco" -cuyo autor es identificado por R. Peinado Santaella con el fraile Sanzones- dirigido a la reina Isabel probablemente en 1482 ya incluía a Cárdenas en la lista de posibles prestamistas a los que sería posible recurrir para sufragar los gastos de la contienda. Descrito como "fechura" de los reyes, el escrito resalta la generosidad de la reina con el Comendador Mayor de León, "el qual se cree tener grandísimo dinero". En efecto, sabemos del relevante papel que había desempeñado previamente Cárdenas en la financiación de la tesorería de la reina gestionada por Fernán Nuñez de Arnalte: el cargo o ingreso del tesorero correspondiente a 1479 recoge la entrega por parte del Comendador Mayor de $2.000 .000 \mathrm{mrs}$ para pagar acostamientos

\footnotetext{
14 Las vías de financiación de la contienda en LAdero Quesada, Castilla y la conquista, pp. 201-224.

15 Resulta imprescindible la tesis doctoral de Federico Gálvez Gambero sobre la deuda pública, leída en la Universidad de Málaga en 2019. GÁlvez Gambero, Endeudamiento y financiación.

16 SÁnchez-CuencA, "Teoría de juegos", pp. 7-8. Posibilidades de aplicación de la "teoría de juegos" en el campo de la Historia económica en Alós Ferrer, "Teoría de juegos e Historia económica”, pp. 27-34.
} 
y sueldos a cambio de la venta de un juro de heredad de 300.000 mrs realizada el mismo $a_{n} o^{17}$. A tenor de estas actividades crediticias previas, Sanzones aseguraba a la reina que Cárdenas "vos puede socorrer para este tan santo abto con lo que vuestra alteza le pidiere, dándole las dichas seguridades". Estas seguridades se referían a la entrega de alguna villa o lugar para "que lo aya en prenda", además de la fe real, tal y como se reconocía en el apartado previo del memorial que apelaba a la posibilidad de que García de Herrera, escudero y vasallo de la reina, aportase 10.000 .000 o $15.000 .000 \mathrm{mrs}$ para la guerra a cambio de que le fuera cedida alguna jurisdicción ${ }^{18}$.

Por lo tanto, la entrega de jurisdicciones señoriales como garantía de devolución de préstamos formaba parte de los proyectos iniciales de financiación de la contienda, aunque con un alcance restringido a un pequeño núcleo de servidores de los reyes. Con ello se anticipaba una dinámica explotada con profusión durante los siglos XVI y XVII que cambiaría netamente el mapa señorial castellano ${ }^{19}$, de la que no obstante, se conocen ejemplos tempranos para la Castilla de fines del siglo XIV ${ }^{20}$. En los primeros compases del conflicto solo Cárdenas se benefició de este mecanismo, posteriormente extensible a importantes nobles como el marqués de Cádiz o don Alfonso de Aguilar, pero siempre con un alcance muy limitado en la medida en que no se buscaba lesionar los derechos de la Corona sobre el realengo ni enajenar "activos públicos"

Sin embargo, en su ejecución práctica, el proyecto inicial fue alterado. En el caso de Cárdenas se buscó atender a su interés por obtener jurisdicciones en el reino de Toledo, señorializadas previamente, como base para conformar el núcleo de lo que mas adelante sería el Ducado de Maqueda, de acuerdo con la capacidad económica que, a tenor del memorial de Sanzones y tal y como ya había demostrado, se le presuponía. Para ello, en lugar de presentarse el traspaso de jurisdicciones señoriales como parte de las seguridades ofrecidas frente al préstamo acordado, se estableció una vía diferente: el vendedor de una determinada villa quedaría obligado a pagar a los reyes el precio de venta concertado por la transacción, que quedaría consignado en calidad de empréstito

\footnotetext{
17 Esta interesante operación de venta de un juro, probablemente la primera en la que se combinaban "el negocio privado con la compra en el mercado primario mediante fondos de procedencia pública", ha sido dada a conocer y analizada por Gálvez Gambero, Endeudamiento y financiación de la Corona de Castilla, pp. 378-382.

18 Peinado Santaella, "Consejos que dio el fraile Sanzones", p. 202.

19 Sobre el proceso de enajenación y venta de jurisdicciones, oficios públicos y rentas durante la época moderna, ver sin ánimo de ser exhaustivo, los trabajos de Marcos Martín, "Sobre desmembraciones, incorporaaciones y ventas", pp. 51-82; MARCOS MARTín, "España en almoneda", pp. 25-65.

20 Ver por ejemplo el préstamo de 3.000 florines de oro del cuño de Aragón que realizó el arzobispo y cabildo de la Iglesia de Toledo a Juan I para financiar los gastos del conflicto con Portugal en 1385, a cambio de los cuales el monarca empeñó la jurisdicción de Torrijos, Esquivias, Yeles, Alcabón y Camarena de Suso, lugares que habían pertenecido a la jurisdicción de la ciudad de Toledo. Esta cuantía debía ser restituida al arzobispo y cabildo toledano por la ciudad de Toledo, con cargo a las alcabalas del cuerpo de la ciudad, según ordenaba el rey el 28 de septiembre de 1389. AHN, Códices 987B, f. 197v. Hernández, Los cartularios de Toledo, doc. 523.

21 Ladero Quesada, Castilla y la conquista del reino de Granada, pp. 218-219. Don Rodrigo Ponce de León recibió en agosto de 1491 la villa de Casares a cambio de un préstamo de $10.000 .000 \mathrm{mrs}$ para la guerra. CAÑAS GÁlvEZ, "Fray Hernando de Talavera", p. 186.
} 
para la guerra. Posteriormente este empréstito sería compensado mediante la cesión de sumas anuales en juro de heredad situadas sobre aquellas rentas regias cuya cobranza podía interesar al vendedor, lo que a efectos prácticos convertía la venta inicial de la jurisdicción en un mecanismo de capitalización del préstamo negociado con los reyes. Este tipo de operación, que afectaba a préstamos de muy elevada cuantía imposibles de satisfacer de otro modo, solo era factible en la medida en que existiese un interés previo por parte del comprador de la jurisdicción -en este caso Cárdenas- en hacerse con su control, de acuerdo con una línea política marcada por la Corona que buscaba beneficiar a uno de sus más leales servidores. Este era, quizás, uno de los principales beneficios perseguidos por el Comendador Mayor de León al plantear su papel mediador.

No obstante, la venta de Maqueda no es el primero ni el único caso en el que los reyes recurrieron a la compra de un señorío por parte de Cárdenas con la finalidad de capitalizar el préstamo realizado por el vendedor de la jurisdicción para sufragar los gastos de la guerra de Granada. La compra de la jurisdicción de las villas de Torrijos y Alcabón, pertenecientes al cabildo de Toledo, formalizada por el Comendador Mayor en 1482 tras obtener el cabildo la bula papal que autorizaba la transacción, se enmarca en una operación similar, justificada por la institución capitular en virtud de los perjuicios y escasa rentabilidad que le ofrecían estas villas como consecuencia de los impedimentos que la ciudad de Toledo establecía a la hora de cobrar ciertos tributos y administrar justicia. De esta forma, los 5.000.000 mrs "para que se puedan comprar heredamientos o rentas perpetuas para la dicha mesa capitular", cuya entrega concertó Cárdenas con el deán y cabildo de Toledo por la compra de Torrijos y Alcabón, según acuerdo alcanzado el 11 de abril de 1482, fueron posteriormente abonados a los reyes en calidad de empréstito para la guerra de Granada ${ }^{22}$.

En efecto, la contabilidad del tesorero de la reina Ruy López de Toledo, que centralizaba la recepta de fondos destinados al pago de las "guardas reales" y otros gastos principales ocasionados por la contienda, incluye entre los $19.944 .772 \mathrm{mrs}$ "de prestidos" recibidos en 1482 "en dineros contados en la corte de Sus Altezas, asy para la guerra de los moros como para los gastos de la cámara de Sus Altezas" 5.000.000 mrs pagados por la Iglesia de Toledo por las tercias adquiridas de Sus Altezas en el arciprestazgo de Montalbán ${ }^{23}$. La entrega partía de la negociación sostenida entre el cabildo y la reina para obtener una compensación por el empréstito, fijada en la percepción de un juro de 333.333 mrs a pagar con cargo a las mencionadas tercias, compradas a precio de 15.000 mrs el millar ${ }^{24}$. Parte de esta renta se refería a 440 fanegas de trigo cobradas en juro de heredad, según privilegio expedido en Toledo el 10 de junio de 1482, a percibir en las

\footnotetext{
22 Pormenores de la operación de venta en CAstro de CAStro, "El Comendador Mayor Gutierre de Cárdenas”, pp. 103-149 y Quintanilla Raso y Blázquez Mayoral, La forja de una casa nobiliaria, pp. 144-145.

23 Cargo de Ruy López de Toledo de 1482. AGS, CMC, $1^{\text {a }}$ ép., leg. 108, sin f. Sobre la actividad del tesorero Ruy López de Toledo ver Ortego Rico, "La financiación de las guardas reales”, pp. 428-473.

24 Quintanilla Raso y BlázQuez Mayoral, La forja de una casa nobiliaria, p. 144. La contabilidad de las alcabalas y tercias del arcedianazgo, cuadrillas y montes de Toledo de 1485 recoge, por ejemplo, dentro del situado que gravaba las rentas del partido $300.000 \mathrm{mrs}$ suspendidos por la merced que tiene
} 
tercias de El Romeral, Melgar, Villanueva de Bogas, El Casar de Remondo, Villamuelas, La Torre, Yepes, Cabañas de Yepes, "las quales se dieron en cuenta e conplimiento de pago de los $\mathrm{V}$ quentos de mrs qu'el dicho deán e cabildo prestaron a Sus Altezas para la guerra de los moros, los quales dichos $\mathrm{V}$ quentos el dicho deán e cabildo ovieron del Comendador Mayor don Gutierre de Cárdenas de la conpra de la villa de Torrijos e Alcavón que d'ellos conpró" ${ }^{25}$. La fecha del privilegio no es anecdótica: el contrato de compraventa entre Cárdenas y el cabildo se había firmado unos días antes (3 de junio de 1482), y cabe suponer que la entrega a la Real Hacienda del precio fijado por la compra de estas rentas solo habría sido efectiva entonces, facilitando la expedición del correspondiente privilegio ${ }^{26}$.

Por lo tanto, la operación de venta del señorío de Torrijos y Alcabón -como en el caso de Maqueda- estaba ligada al uso posterior del dinero por parte del deán y cabildo toledano para comprar a la Corona juros de heredad, de los cuales la institución pasaría a ser beneficiaria en compensación por la suma entregada. Por su parte, la cantidad otorgada quedaría conceptualizada como empréstito para la guerra de Granada. Con ello, de esta negociación "a tres bandas" todas las partes (Corona, comprador y vendedor) lograban beneficios: los reyes obtenían cuantiosos recursos líquidos de forma rápida destinados a la guerra, el comprador (Cárdenas) nuevas bases de dominio señorial que incentivaban la operación, y el vendedor (el cabildo de Toledo) se deshacía de una jurisdicción cuya gestión consideraba poco rentable y concentraba el capital obtenido de la venta en la adquisición de rentas líquidas más seguras y fáciles de cobrar, o que exigían de una logística menos compleja que la necesaria para la gestión señorial, amén de que también podría exhibir su compromiso económico con una causa "justa" y "santa".

En el caso de la venta de Maqueda y el empréstito de Alonso Carrillo la dinámica fue muy similar, con la particularidad de que la cuantía del préstamo y los objetivos políticos a cubrir eran mucho más amplios. No vamos a insistir en el proceso legal seguido, habida cuenta de que se alejaría de los verdaderos objetivos de este trabajo y es bien conocido. No obstante, la documentación conservada en el Fondo Rodríguez Marín del CSIC referida a este asunto para los años 1479-1491, permite contextualizar desde un punto de vista político y financiero el contrato suscrito, en una encrucijada de intereses que afectaban a los Reyes Católicos, a Cárdenas y a Carrillo.

Por una parte, tal y como ha señalado A. Franco Silva, el préstamo de 16.000.000 mrs abonado en 1483 estaba inserto en la política de reconciliación de Alonso Carrillo de Acuña y su linaje con los reyes en un momento que exigía unidad ante la empresa común que representaba la guerra de Granada. Cabe recordar que, siguiendo la línea

el cabildo de Toledo de las tercias de las Sislas, arciprestazgo de Montalbán, Corral de Torcón y Menas Albas. AGS, EMR, leg. 36, f. 47.

25 Asiento de $92.400 \mathrm{mrs}$ pagados por el mencionado privilegio en cuenta de las 440 fanegas de trigo,

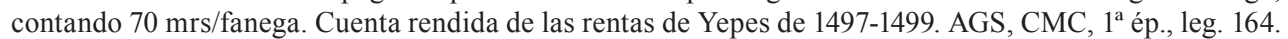

26 Quintanilla Raso y Blázquez Mayoral, La forja de una casa nobiliaria, p. 145. 
marcada por su tío, el arzobispo de Toledo homónimo ${ }^{27}$, Carrillo apoyó inicialmente la causa de doña Juana y la invasión portuguesa de Alfonso $\mathrm{V}^{28}$, aunque posteriormente habría aconsejado a su tío defender los derechos de Isabel ${ }^{29}$. Por lo tanto, su contribución económica -recordemos que fue la más elevada de cuantas se ofrecieron por parte de instituciones y particulares en el transcurso del decenio que duró la guerra de Granada- podía ser entendida desde el punto de vista de la creación de un consenso político renovado con la monarquía de los Reyes Católicos y sus proyectos.

Por otra parte, Alonso Carrillo de Acuña y sus patrimonios caracenses y toledanos atravesaron dificultades a comienzos de la década de 1480, especialmente manifiestas por el incumplimiento de algunos de los acuerdos pactados en el trueque que años antes, en noviembre de 1470, había concertado con el obispo de Sigüenza Pedro González de Mendoza, para la permuta de la villa de Maqueda a cambio de las fortalezas de Jadraque y de Alcorlo, en la actual provincia de Guadalajara. Ello llevaría a Mendoza, el 25 de octubre de 1483, ya como nuevo arzobispo de Toledo y contando con la garantía de los monarcas, a interponer un pleito contra Carrillo ante el Consejo Real que no finalizaría hasta $1484^{30}$.

Fue en aquel contexto, marcado por los problemas de los monarcas para dar respaldo financiero al conflicto con el emirato nazarí, cuando el guarda mayor aceleró la venta definitiva de Maqueda a Cárdenas con el objetivo de obtener liquidez y cumplir con el préstamo concertado con los reyes "para las neçesydades que a la sazón les acarrearon de complir para la guerra de los moros, enemigos de nuestra sancta fe católica". En efecto, el propio Carrillo reconocía el 7 de abril de 1491 a los monarcas en el documento por el cual se daba por satisfecho tras la restitución definitiva del empréstito, que "les socorrí con diez e seys quentos de maravedíes de los maravedíes que así me dio y pagó dicho Comendador Mayor" ${ }_{31}$. Por lo tanto el trasfondo completo de esta operación partía realmente de las condiciones fijadas para la venta de Maqueda. No obstante, pese a que Carrillo de Acuña manifestaba en 1491 haber recibido de Gutierre de Cárdenas la totalidad del importe completo de la venta de la villa ${ }^{32}$, cifrado en $17.150 .000 \mathrm{mrs}$, en realidad sabemos que esto no fue asín ${ }^{33}$.

\footnotetext{
27 Sobre la figura del prelado y su postura durante el conflicto sucesorio, ver sin ánimo de exhaustividad, DíAz IBÁÑ̃z, "El arzobispo Alfonso Carrillo de Acuña", pp. 158-164.

28 Como hicieron otros grandes nobles castellanos que apoyaron la causa política de Juana y Alfonso V de Portugal después de la pacificación de 1479. Entre otros, Rodrigo Ponce de León, quien también concedió a los Reyes Católicos un notable préstamo de 10.000.000 mrs para la guerra de Granada. Franco Silva, La fortuna y el poder, pp. 222-223. Rivera Recio, Los arzobispos de Toledo, pp. 119-122. Ladero Quesada, La Hacienda Real de Castilla, 1369-1504, pp. 226 y 238.

29 Díaz IbÁÑEz, "El arzobispo Alfonso Carrillo de Acuña", p. 186.

30 Lo apunta Quintanilla Raso y Blázquez Mayoral, La forja de una casa nobiliaria, p. 173 y sobre todo lo estudia Villalba Ruiz de Toledo, "Reajustes de señoríos en el siglo XV", pp. 1763-1779. Véase también Villalba Ruiz de Toledo, El cardenal Mendoza.

31 AFRM, Caja 98, leg. 1, doc. 22.

32 AFRM, Caja 98, leg. 1, doc. 22.

33 AFRM. Caja 98, leg. 1, doc. 14 (a). Vid. infra.
} 
En definitiva, la documentación conservada pone en evidencia el verdadero alcance del préstamo de Carrillo y la venta de Maqueda. Como en el caso ya señalado del empréstito del cabildo de Toledo y la venta de Torrijos y Alcabón, ambas operaciones partían de una convergencia de intereses, catalizados por la iniciativa de la Corona ante el escenario bélico y por las circunstancias particulares de estos agentes, que intentaron maximizar sus beneficios económicos y políticos. Desde el punto de vista financiero el acuerdo alcanzado abría la puerta a la capitalización del préstamo de Carrillo. Por otra parte, desde una óptica política los reyes podían gratificar los servicios ofrecidos por Cárdenas con una nueva base de poder señorial de su interés, cuya adquisición se había visto entorpecida previamente y quedaba aparentemente desbloqueada. De igual forma, la operación ofrecía una oportunidad a la integración política de Carrillo a cambio de un relevante servicio económico, recompensado por los reyes -según se verá- con la cesión de rentas en juro de heredad, tenencias de fortalezas y nuevos señoríos en espacios donde el noble aspiraba a consolidar su proyección política y patrimonial. Aparentemente, todas las partes ganaban -en mayor o menor medida- con la operación.

\subsection{Intermediarios y medios de pago}

El procedimiento establecido para el abono del empréstito de Alonso Carrillo es bien conocido gracias a los documentos que quedaron en poder de Gutierre de Cárdenas referidos a esta operación, habida cuenta de su papel como principal intermediario reconocido por la Corona. En primer lugar, una vez formalizada la venta de Maqueda el 3 de febrero de 1483 en Madridd $^{34}$, Cárdenas buscó asegurar la transacción mediante instrumentos notariales que acreditaran la realización del pago. Para ello, el 21 de febrero de 1483 Alonso Carrillo reconocía a instancias de Cárdenas mediante escritura firmada en Madrid darse por satisfecho por la entrega de los $17.150 .000 \mathrm{mrs}$ realizada a su favor por el Comendador Mayor de León ${ }^{35}$. La expedición de este documento no se entiende sin atender a las circunstancias que rodearon esta operación, vinculadas con el préstamo de Carrillo para la guerra de Granada acordado paralelamente con los reyes. De esta forma, la carta de pago explicitaba que los $17.150 .000 \mathrm{mrs}$ en "monedas de oro de castellanos e ducados e doblas e florines e reales e cadenas de oro e pieças de plata apreçiadas en su valor", entregados en Madrid a Carrillo por Cárdenas en el momento de realizar la venta, habían quedado en poder de diversas personas apoderadas por el guarda mayor: tal y como se vio obligado a reconocer este último, la suma era tan abultada que "no ove lugar en manera de los poner en otro cabo". Por otra parte, el documento dado por Carrillo respondía a la necesidad de Cárdenas de tener constancia notarial del pago realizado a los supuestos apoderados designados por Carrillo para hacerse cargo del dinero, a fin de salvaguardar sus derechos ante una hipotética reclamación futura. El principal escollo era-según declaraba el guarda mayor-que "los

\footnotetext{
AFRM, Caja 98, leg. 1, doc. 32.

35 AFRM, Caja 98, leg. 1, doc. 14 (a).
} 
dichos escrivanos e testigos de la dicha escriptura de venta non vieron fazer realmente la paga d'ellos segunt que en la verdad avía seydo e lo yo avía resçebido". De este modo, con la escritura aportada por Carrillo, rubricada de su puño y letra, Cárdenas aseguraba sus derechos sobre Maqueda y evitaba la posibilidad de que el dinero entregado fuera considerado a posteriori como parte de un acto simulado o fingido, sin duda porque la inmensa mayoría de las sumas entregadas por la operación no llegaron nunca a estar en poder de Alonso Carrillo al haber quedado comprometidas para financiar el préstamo concertado con los reyes ${ }^{36}$. Se trataba, en definitiva, de revestir la venta de todas las garantías jurídicas posibles, creando una "ficción jurídico-legal" sobre un acto -la entrega de la totalidad del dinero- que realmente nunca tuvo lugar.

De la importancia en términos políticos, y no solo jurídicos o económicos, de este instrumento notarial da cuenta la lista de testigos que suscribieron, a petición de Carrillo, el documento y dieron "entera e conplida fee como personas públicas al dicho señor Comendador Mayor cómo vieron realmente la dicha paga en mi poder a toda mi guisa e voluntad e contentamiento". La mayoría pertenecía al "equipo de gobierno" de los reyes, y desempeñaba oficios burocráticos relevantes en la corte regia o en la administración territorial de la monarquía, por lo que muchos de ellos acompañaban en sus desplazamientos a los monarcas, aposentados en aquel momento en Madrid.

Así, el madrileño Francisco Ramírez [de Madrid] "El Artillero", era secretario de los reyes y estaba casado con Beatriz Galindo, dama y amiga de la reina Isabel ${ }^{37}$; el testigo Hernando de Zafra sin duda cabe identificarlo con el futuro secretario de los reyes homónimo, que había sido contador de relaciones desde 1474, y debió tener en el desempeño de su oficio trato fluido con Cárdenas, pero sobre todo con el contador mayor Rodrigo de Ulloa, del que era criado en 148238; por su parte, el licenciado Andrés Calderón era miembro del Consejo Real y alcalde de Casa y corte, mientras que el bachiller Pedro [Díaz] de la Torre era procurador fiscal de los monarcas ${ }^{39}$; Pedro [Arias] de Ávila miembro de la importante familia conversa de origen segoviano Arias Dávila- había sido alcaide de Puñoenrostro, y Pedro de Baeza lo era de la fortaleza de Escalona. Otros testigos, como Rodrigo de Mercado, vecino de Medina del Campo, Alonso Ordóñez de Villaquirán, o Vasco de Vivero, vecino de Salamanca, ocupaban o habían ocupado corregimientos de villas y ciudades en nombre de los reyes ${ }^{40}$.

\footnotetext{
36 AFRM, Caja, 98, leg. 1, doc. 14 (a). Así lo indica también Quintanilla Raso y Blázquez Mayoral, La forja de una casa nobiliaria, p. 177, nota 130.

37 Porras Arboledas, "El secretario real Francisco Ramírez de Madrid”, pp. 169-182.

38 Ladero Quesada, Hernando de Zafra, pp. 17-18.

39 Aparece mencionado como procurador fiscal en el emplazamiento dado el 2 de febrero de 1485 en Sevilla por los reyes contra Martín Fernández de Tovar, antes llamado Juan de Tovar, por los delitos de lesa majestad que este último había cometido desde 1478 y por su unión junto al arzobispo de Toledo Alonso Carrillo de Acuña con la intención de apoyar a Alfonso V de Portugal. AGS, RGS, febrero de 1485 , f. 250.

40 Rodrigo de Mercado suscribe el documento notarial como corregidor. Por su parte, Alonso Ordóñez de Villaquirán fue nombrado corregidor de León en 1480. AGS, RGS, enero de 1480, f. 7. El oficio le fue prorrogado por un año, para 1481. AGS, RGS, diciembre de 1480, f. 19. Vasco de Vivero había sido
} 
Además de Hernando de Zafra, los testigos que ocupaban oficios en la administración hacendística, o relacionados con algunos de los oficiales del fisco regio, también contaban con una nutrida representación en el listado, probablemente en virtud de las relaciones de confianza articuladas con Gutierre de Cárdenas a partir del desempeño de este último como contador mayor de los reyes, y de las connotaciones hacendísticas de la operación: Gonzalo de Baeza era contador y tesorero de la reina ${ }^{41}$; Juan de Ulloa, vecino de Toro, era hijo del contador mayor Rodrigo de Ulloa ${ }^{42}$; el doctor Juan Díaz de Alcocer prestaba sus servicios como contador mayor de cuentas de los reyes y era miembro del Consejo Real ${ }^{43}$. Además de estos agentes, dotados de un claro perfil político, también suscribieron el instrumento notarial Sancho de la Plazuela y Jerónimo, hijos de los dos escribanos públicos madrileños que dieron fe de la escritura, a la sazón Diego Rodríguez y Ruy Fernández. La lista la cerraban Fernando de Guzmán, Fernando de Ruiseco, Rodrigo de Castañeda y Alonso de Ludueña, escuderos de Alonso Carrillo.

No obstante, la venta de Maqueda plantea algunas preguntas de difícil respuesta. Pese a la solvencia económica atribuida a Gutierre de Cárdenas, ¿cómo pudo reunir en tan poco tiempo una cantidad de dinero líquido tan elevada para afrontar la operación? ¿Cuáles eran sus fuentes de ingreso y/o capitalización? ¿Hubo financieros encargados de adelantarle parte de estas sumas? De ser así, ¿qué compromisos y contraprestaciones suscribió? ¿Estaban estos compromisos respaldados por los reyes? Lo que es seguro es que del precio de 17.150.000 mrs fijado por la venta de Maqueda tan solo $1.150 .000 \mathrm{mrs}$ habrían sido percibidos por el guarda mayor. Los $16.000 .000 \mathrm{mrs}$ restantes $(93,3 \%$ del total) fueron a parar a manos de fray Hernando de Talavera a lo largo de 1483. El jerónimo, confesor de Isabel I y prior de Santa María de Prado, quedó encargado desde 1482 de administrar la mayoría de los recursos destinados a sufragar la guerra de Granada, entre ellos los préstamos entregados por particulares e instituciones, o el dinero procedente de la bula de cruzada y la décima habida cuenta de la confianza que la reina tenía en él despositada como buena conocedora de su honradez y capacidad de trabajo y organizativa, ya observada desde sus primeros encargos hacendísticos; a saber, la gestión del empréstito de la plata de las iglesias de 1476 y la reducción del "situado" de la Real Hacienda en $1480^{44}$. El 10 de octubre de 1483 Talavera reconocía en carta de pago dada en Vitoria haber recibido de Gutierre de Cárdenas, y de algunas personas por su mandato, los $16.000 .000 \mathrm{mrs}$ del "socorro" concertado con Carrillo, en nombre de este último, al que probablemente

corregidor de Cáceres en 1475, y de La Coruña al menos en 1478 y 1480-1481. AGS, RGS, julio de 1478, f. 1; marzo de 1480, f. 10; diciembre de 1480, f. 21.

${ }^{41}$ Son bien conocidas sus cuentas de tesorería. Torre y del Cerro, Cuentas de Gonzalo de Baeza, 2 vols.

42 Voz "Rodrigo de Ulloa" elaborada por D.C. Morales Muñiz. Diccionario Biográfico Español, Real Academia de la Historia. http://dbe.rah.es/biografias/56974/rodrigo-de-ulloa.

43 Rábade Obradó, "Apuntes biográficos de un servidor de los Reyes Católicos", pp. 259-288.

44 Ladero Quesada, "Fray Hernando de Talavera", pp. 264-265. Ortego Rico, "Las riquezas de la Iglesia", pp. 154, 162 y 173-174. Sobre el papel mediador de Talavera y la entrega y restitución de los préstamos realizados por el marqués de Cádiz don Rodrigo Ponce de León ver CAÑAS Gálvez, "Fray Hernando de Talavera”, pp. 181-186. 
se dio otra carta de pago semejante, como parece indicar el documento. El abono de esta cantidad se llevó a cabo en varios plazos: entre marzo y abril el Comendador Mayor entregaba en Madrid un total de 15.029.421 mrs, parte de la suma -no toda- comprometida por la compra de Maqueda en febrero, y realmente nunca entregada de manera efectiva al guarda mayor pese a lo señalado en el instrumento notarial que este había expedido a favor de Cárdenas en febrero de 1483; en mayo, el camarero de Cárdenas Hernando Sedeño abonaba en Santo Domingo de la Calzada 461.438 mrs; por su parte, en agosto de 1483 Alonso Vázquez, capellán del Comendador Mayor, pagaba 310.000 mrs en Córdoba a Juan de la Torre, vecino de Carrión y representante de Talavera; finalmente, el mismo día en que Talavera daba su carta de pago, Cárdenas abonaba en Vitoria los últimos 215.168 mrs. Con ello quedaban cubiertos los 16.000 .000 mrs del préstamo de Carrillo y 16.107 mrs pagados a Gonzalo Fernández de Alcalá y Juan de la Torre, según estipularon Gonzalo de Baeza y Francisco de Illescas, por "las menguas que ovo en el dicho oro", resultado de las diferencias en la ley y hechura de algunas de las piezas entregadas ${ }^{45}$.

A tenor de la carta expedida por el Prior de Prado, los medios de pago utilizados por Cárdenas combinaron el abono de abultadas cantidades de moneda con la entrega de alhajas y piezas de oro y plata labrada, que necesitaron ser tasadas. De esta forma, se constata la entrega a fray Hernando de Talavera de $13.432 .687 \mathrm{mrs}(83,95 \%$ del total de $16.000 .000 \mathrm{mrs})$ en $88.735,5$ monedas de oro y plata. De otros $771.438 \mathrm{mrs}(4,82$ \%) no se especifica la moneda en la cual se efectuó el abono (vid. tabla 1). En cualquier caso, la carta de pago es representativa de los diferentes tipos de piezas "fuertes" que circulaban en Castilla, más allá de las autóctonas, o que formaban parte de los depósitos de numerario atesorados por hombres como Cárdenas, así como de sus precios de cambio oficiales una vez estabilizado el sistema monetario castellano entre 1471 y $1483^{46}$.

Lógicamente no todas estas monedas tenían la misma importancia. Ante todo, se observa la preferencia de Cárdenas por el pago en moneda de oro, de mayor poder adquisitivo. En total, el Comendador Mayor entregó a fray Hernando de Talavera 27.068,5 piezas equivalentes a $11.521 .127 \mathrm{mrs}$ y al $72 \%$ del préstamo. Un $45 \%$ (7.198.612 mrs) quedó cubierto con "castellanos" de oro -nueva versión acuñada desde 1475 de la dobla castellana de ley de 23,75 quilates y 50 piezas por marco-, cuyo curso legal estaba fijado en $485 \mathrm{mrs} /$ pieza. Se sumaban $1.845 .805 \mathrm{mrs}$ (11,54 \% del total del préstamo) pagados en 5.057 doblas "de la banda" de peor ley (a $265 \mathrm{mrs} /$ pieza), muy abundantes en Castilla desde que Juan II comenzara su acuñación en la década de 1430. Otro 7,97 $\%$ (1.275.750 mrs) fue abonado en 3.402 "ducados cruzados" portugueses a $375 \mathrm{mrs} /$ pieza, emitidos con ley de 23,75 quilates y 64 piezas por marco desde 1457 por Alfonso V (1438-1481) gracias a la disponibilidad de oro tras las conquistas y exploraciones africanas llevadas a cabo por el monarca luso ${ }^{47}$. Por el contrario, los florines "del cuño

\footnotetext{
45 Documento original en AFRM, Caja 98, leg. 1, doc. 15. Publicado en el apéndice de este mismo trabajo. Quintanilla Raso y Blázquez Mayoral, La forja de una casa nobiliaria, pp. 177-178.

46 Sobre los aspectos monetarios de la época ver LAdero Quesada, La Hacienda Real de Castilla, 13691504, pp. 763-808; Francisco Olmos, “La evolución de los cambios monetarios”, pp. 115-142.

47 Teixeira de Aragão, Descripção geral e histórica das moedas, pp. 230 y 242.
} 
de Aragón", de menor poder adquisitivo (ley de 18 quilates y talla de 68 piezas por marco), apenas suponían un 4,03\% del préstamo (645.275 mrs).

En este sentido, la presencia de una cantidad tan importante de moneda portuguesa es un buen indicador de la intensidad de los nexos entre ambos reinos y de la paz alcanzada tras la firma del tratado de Alcaçovas-Toledo de 1479-148048. Aunque es probable que la condición de Cárdenas como Comendador Mayor de la orden de Santiago en la Provincia de León -cuyo señoríos se ubicaban en la frontera con Portugal- también guarde alguna relación con esta presencia de numerario luso, quizás procedente de transacciones relacionadas con el pago de rentas de la orden, de la que su primo Alonso de Cárdenas era maestre desde 1477, aunque los territorios portugueses habían quedado definitivamente desligados de la obediencia al maestre castellano tras muchos debates zanjados por bula de Nicolás V dada en $1452^{49}$. Ello ratificaría la hipótesis formulada por Gálvez Gambero acerca de la posibilidad de que Cárdenas hubiera desviado recursos de la mesa maestral de la orden de Santiago para financiar a la monarquía, tal y como apunta el préstamo de 2.000.000 mrs realizado por el Comendador Mayor en 1479 para financiar la tesorería de la reina ${ }^{50}$. ¿Pudieron proceder de las rentas maestrales santiaguistas buena parte de los recursos líquidos pagados en moneda castellana y lusa destinados por Cárdenas para comprar la jurisdicción de Maqueda y capitalizar de este modo el préstamo de Carrillo? No parece una hipótesis descabellada: cabe recordar que en las negociaciones que en septiembre de 1477 llevaron a Alonso de Cárdenas a obtener el maestrazgo de Santiago se incluyó la entrega de 3.000 .000 mrs procedentes de las rentas de la mesa maestral para financiar el abastecimiento de castillos en la frontera granadina ${ }^{51}$.

Otras monedas de oro, autóctonas o extranjeras, tienen una recurrencia menor. Cárdenas únicamente entregó 412 "enriques viejos" -se trataba de una dobla de menor ley (23 quilates o algo menos) acuñada por Enrique IV durante la primera mitad de su reinado- que todavía seguían circulando: en total 412 piezas valoradas en $195.700 \mathrm{mrs}$ $(1,22 \%$ del préstamo). También figuran $163.125 \mathrm{mrs}$ pagados en diferentes tipos de ducados (genoveses, florentinos, romanos, sieneses, milaneses, napolitanos, de Ferrara y húngaros), todos ellos con curso legal de $375 \mathrm{mrs} /$ pieza, indicativos de la presencia de colonias mercantiles italianas en territorio castellano y de los estrechos vínculos económicos y políticos que unían Italia con la Península Ibérica. No obstante, su escasa recurrencia (435 piezas) muestra la falta de integración de Castilla en el ámbito de dominio de esta divisa internacional, solo iniciada a partir de 1497. Por su parte, de las relaciones con Granada da fe la entrega de 227 doblas de oro "zeyenes", de peor ley que las castellanas, valoradas en $440 \mathrm{mrs} /$ pieza (99.880 mrs equivalentes al 0,62 \%).

\footnotetext{
48 Las relaciones económicas en los ámbitos fronterizos luso-castellanos y la creación de un espacio económica portugués, en el que la acuñación de moneda tendría una importancia destacada, en CosTA, "O espaço económico", pp. 143-153.

49 Sobre este proceso ver Ayala Martínez, "La escisión de los santiaguistas portugueses”, pp. 53-70.

50 Gálvez Gambero, Endeudamiento y financiación de la Corona de Castilla, pp. 379-380. Agradecemos al autor la posibilidad ofrecida de consultar su tesis y las sugerencias dadas al respecto sobre esta cuestión. 51 Quintanilla Raso y BlázQuez Mayoral, La forja de una casa nobiliaria, pp. 71-72.
} 
Las restantes monedas de oro extranjeras representadas apenas tienen relevancia cuantitativa: 164 "coronas" francesas a $355 \mathrm{mrs} /$ pieza (58.220 mrs), 2 "nobles" de Inglaterra a $750 \mathrm{mrs} /$ pieza (1.500 mrs) y 92 "águilas” de Sicilia a $405 \mathrm{mrs} /$ pieza (37.260 mrs). En este último caso, la presencia de moneda siciliana acaso guarde relación con la administración de la Cámara Reginal siciliana, bajo el dominio de la reina Isabel I desde su matrimonio con Fernando, monarca de Sicilia desde 146852. Mayor importancia tenía la moneda de plata "fuerte", muy frecuente en las transacciones económicas de la época: Cárdenas entregó 61.667 reales de plata a $31 \mathrm{mrs} /$ pieza, que cubrieron casi un $12 \%$ del total del préstamo (1.911.677 mrs), aunque el limitado poder adquisitivo de estas piezas las hacía menos operativas a la hora de afrontar un pago de estas características. Por su parte, los 125 mrs abonados en "dineros" deben corresponder a entregas en moneda de vellón.

Tabla 1.

Monedas entregadas por Gutierre de Cárdenas a fray Hernando de Talavera en 1483 para cubrir el préstamo de 16.000.000 mrs de Alonso Carrillo de Acuña

\begin{tabular}{|c|c|c|c|c|}
\hline Tipo de moneda & $\begin{array}{l}\mathbf{N}^{0} \text { piezas } \\
\text { entregadas }\end{array}$ & $\begin{array}{c}\text { Equivalencia } \\
\text { moneda en mrs }\end{array}$ & Total en mrs & $\begin{array}{l}\text { \% sobre } \\
\text { el total del } \\
\text { préstamo }\end{array}$ \\
\hline Castellanos & $14.842,5$ & 485 & 7.198 .612 & 44,99 \\
\hline Doblas & 5.057 & 365 & 1.845 .805 & 11,54 \\
\hline Ducados cruzados & 3.402 & 375 & 1.275 .750 & 7,97 \\
\hline Florines de Aragón & 2.435 & 265 & 645.275 & 4,03 \\
\hline Enriques viejos & 412 & 475 & 195.700 & 1,22 \\
\hline $\begin{array}{l}\text { Ducados de Génova, Florencia, } \\
\text { Roma, Hungría, Siena, Milán, } \\
\text { Nápoles y Ferrara }\end{array}$ & 435 & 375 & 163.125 & 1,02 \\
\hline Doblas zeyenes & 227 & 440 & 99.880 & 0,62 \\
\hline Coronas & 164 & 355 & 58.220 & 0,36 \\
\hline Águilas de Sicilia & 92 & 405 & 37.260 & 0,23 \\
\hline Nobles de Inglaterra & 2 & 750 & 1.500 & 0,01 \\
\hline Reales & 61.667 & 31 & 1.911 .677 & 11,95 \\
\hline Dineros (sin especificar) & & & 125 & 0,00 \\
\hline $\begin{array}{l}\text { Cuantías entregadas sin especi- } \\
\text { ficar moneda }\end{array}$ & & & 771.438 & 4,82 \\
\hline TOTAL & 88.735 & & 14.204 .367 & 88,78 \\
\hline
\end{tabular}

52 Sabemos, en este sentido, que años más tarde Juan de Cárdenas -sobrino de Gutierre de Cárdenasfue nombrado gobernador de la Cámara Reginal de Sicilia. El 22 de mayo de 1488 los reyes mandaban librarle $100.000 \mathrm{mrs}$ de ayuda de costa con cargo a las alcabalas y tercias del partido de Ciudad Real de

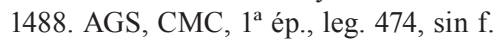


Además del pago con estas monedas, para terminar de cubrir la compra de Maqueda y el dinero correspondiente al préstamo de Carrillo, Gutierre de Cárdenas también recurrió a alhajas y piezas "de oro e plata labrada, blanca y dorada" que se encontraban bajo su custodia y fue necesario tasar. Su entrega acaso resulta sintomática de sus dificultades para obtener liquidez por otros medios. Sea como fuere, la carta de pago de Talavera recoge la entrega en marzo y abril de tres cadenas y un riel de oro, que pesaron 682 castellanos, de los cuales los jueces Gonzalo López de la Fuente y Francisco de Illescas, descontaron 10 castellanos y medio "de menguas de ley y de la hechura", con lo que su equivalencia se fijó en 325.677 mrs o 671 castellanos. También se hace alusión a ciertas piezas de plata labrada y dorada entregadas en Madrid, que pesaron 387 marcos, 2 onzas y 2 ochavas, tasadas por Gonzalo López, Francisco de Illescas, Francisco Cota y el platero Fernando en 1.170.395 mrs.

Mayor importancia tenía en términos políticos, aunque no cuantitativos, la entrega a Talavera de una cadena grande de oro fino "del rey nuestro señor", tasada en 300.000 mrs y mpeñada por esta cantidad al Comendador Mayor de León, quizás como garantía de restitución de algún préstamo previo y siguiendo una pauta bien conocida para la época cuyo alcance propagandístico es evidente ${ }^{53}$. La misma cadena debió servir poco después como garantía de restitución de otros préstamos para la guerra de Granada. Así lo confirma un asiento de las cuentas del tesorero Ruy López de Toledo de 1483 en el que se consigna un gasto de 300.000 mrs pagados por albalá regio a Juan de la Torre, criado de fray Hernando de Talavera, "que Su Alteza avía resçebido prestadas del dicho prior sobre una cadena de oro grande qu'el dicho thesorero dyo a Su Alteza en la çibdad de Bitoria en el mes de novienbre del dicho año"s4. Completaba la relación de piezas un platel, dos escudillas y cuatro "cuchares" de plata blanca entregados por Cárdenas a Talavera en Vitoria el 10 de octubre de 1483, que pesaron 7 marcos, una onza y 2 reales de plata: a tenor del precio de $2.050 \mathrm{mrs} /$ marco su equivalencia se estableció en $14.668 \mathrm{mrs}$. En total, las alhajas y piezas de oro y plata entregadas permitieron cubrir un $11 \%$ de la totalidad del préstamo $(1.811 .670 \mathrm{mrs})$ por lo que su importancia no es en absoluto desdeñable.

Una vez en poder de fray Hernando de Talavera, estas cantidades en su inmensa mayoría fueron entregadas al tesorero de la reina Ruy López de Toledo, para que este pudiera pagar con cargo a estos y otros recursos los sueldos de los contingentes militares que combatían en la guerra de Granada o estaban destacados aquel año en la frontera de Navarra. El cargo o ingreso del tesorero correspondiente a 1483 recoge un total de $23.550 .000 \mathrm{mrs}$ ( $36 \%$ del total ingresado) recibidos del Prior de Prado por ciertos mandamientos de los reyes. Uno de ellos, expedido en Madrid en abril de 1483, correspondía a 5.000.000 mrs, pagados en nombre de Talavera por Gonzalo Fernández "el sayón". Los restantes $18.550 .000 \mathrm{mrs}$ se abonaron a Ruy López de Toledo por diversos mandatos del rey dados en Córdoba en mayo de 1483 hasta fin de agosto del mismo año

\footnotetext{
3 Gálvez Gambero, Endeudamiento y financiación de la Corona de Castilla, pp. 381-382.

${ }^{54}$ AGS, CMC, $1^{\circ}$ ép., leg. 106, sin f.
} 
"que Su Alteza estovo faziendo la guerra a los moros". El responsable de pagar estas cuantías al tesorero de la reina fue de nuevo Juan de la Torre, criado e intermediario de Talavera, que también se encargó de portar los mandamientos de Su Alteza y las cartas de pago del tesorero. Ya ha quedado señalada, en este sentido, su participación en la recepta de algunas de las sumas entregadas por Gutierre de Cárdenas correspondientes al préstamo de Carrillo.

Más adelante, Ruy López de Toledo recibía por mandamiento dado por los reyes en Vitoria en diciembre de 1483 otros 124.000 mrs de fray Hernando de Talavera, "los quales fueron para gastos tocantes a la dicha guerra de los moros" desde abril de 1483 hasta noviembre de 1483. De nuevo, cabe suponer -aunque la cuenta del tesorero de la reina no lo explicite- que esta suma era parte de los $215.178 \mathrm{mrs}$ entregados el $10 \mathrm{de}$ octubre de 1483 por el Comendador Mayor de León al Prior de Prado correspondientes al último pago realizado para terminar de cubrir el empréstito de Carrillo ${ }^{55}$.

Con ello finalizaban las diferentes transferencias de dinero a las que había dado lugar la compra de Maqueda y el pago del préstamo en 1483. La importancia de la operación en términos cuantitativos queda de manifiesto si se tiene en cuenta que la inyección de estos 16.000.000 mrs permitió financiar en un 25 \% la tesorería de Ruy López de Toledo en 1483, junto a otros recursos como libranzas sobre las rentas regias ordinarias, "socorros", libranzas con cargo a la contribución de la Hermandad, otros empréstitos y el alcance de la cuenta del tesorero de la reina de $1482^{56}$. Si bien el pago del préstamo no había revestido en apariencia grandes problemas, más allá de los vinculados con unas negociaciones políticas cuyo contenido y desarrollo exacto desconocemos y con la dificultad de reunir una suma tan elevada, sin embargo su amortización se dilató notablemente hasta su cancelación definitiva en 1491.

\section{La compleja amortización: renegociar el préstamo y maximizar beneficios}

Los mecanismos para amortizar un préstamo tan elevado se establecieron mediante unas capitulaciones concertadas entre los reyes y Alonso Carrillo, presumiblemente suscritas antes del 4 de febrero de $1483^{57}$, en las que quedaron fijadas las condiciones que permitirían compensar el importe entregado de manera efectiva por Cárdenas. En este sentido, aunque el impulso a la venta de Maqueda pudiese responder a la necesidad de capitalizar el empréstito de Carrillo mediante el dinero conseguido por el Comendador Mayor de León para comprar la jurisdicción, lo cierto es que, desde la perspectiva de Carrillo, las generosas compensaciones negociadas de forma paralela con los reyes tenían como finalidad asentar nuevas bases de poder -señoriales y económicas- en aquellos espacios

\footnotetext{
55 Cargo de Ruy López de Toledo de 1483 en AGS, CMC, $1^{\text {a }}$ ép., leg. 106, sin f.

56 Resumen de la procedencia y cuantía de estos ingresos en ORTEGo Rico, "La financiación de las guardas reales", p. 445.

57 En esta fecha ya se había expedido una carta de libramiento por parte de los reyes correspondiente a parte del pago de las cuantías fijadas para amortizar el préstamo, en concreto 600.000 mrs librados con cargo a las alcabalas, tercias y otras rentas de Molina de Aragón y su tierra. Vid. infra.
} 
en los que su linaje contaba con intereses o aspiraba a tener una mayor proyección. Por lo tanto, la negociación en torno a la restitución del préstamo formaba parte de una calculada estrategia política que buscaba racionalizar y maximizar los beneficios, y no solo obtener un mero aprovechamiento económico.

\subsection{Las capitulaciones de 1483 y la entrega de Molina y sus rentas como prenda}

Estas capitulaciones de 1483 -que fueron objeto, como veremos, de constantes renegociaciones que ampliaron cada vez más el radio de acción político-económica del guarda mayor- no se han conservado, o no se han podido localizar. No obstante, tanto la carta real de merced entregando la jurisdicción de Caracena a Alonso Carrillo dada en Sevilla el 26 de marzo de $1491^{58}$, como la carta de pago y finiquito expedida por el guarda mayor a favor de los monarcas en Sevilla el 7 de abril de 1491, con la que concluía el proceso de amortización del préstamo ${ }^{59}$, aportan numerosos detalles sobre las vicisitudes y constantes reformulaciones por las cuales atravesó la cancelación del empréstito durante casi una década. El proceso tiene interés por dos motivos: por un lado, constituye un ejemplo casi único para la Castilla de la época en la medida en que la documentación conservada permite profundizar en la comprensión de este tipo de operaciones crediticias complejas, imposibles de conocer para la inmensa mayoría de los préstamos $^{60}$; por otro lado, fue un "ensayo" de nuevos mecanismos de amortización de la deuda de la Corona procedente de préstamos que, una vez mejorados y consolidados, terminarían provocando "mutaciones" en el sistema hacendístico imprimiendo algunos rasgos distintivos potenciados ya durante el siglo XVI.

En el primer acuerdo al que llegaron los reyes con Carrillo en 1483 se reconocía, como compensación por el empréstito, la entrega de 1.000 vasallos en ciertos lugares del reino y $600.000 \mathrm{mrs}$ de renta que el guarda mayor podría "aver y conprar por los dichos diez e seys quentos de maravedíes". Por lo tanto, la amortización se concebía bajo premisas similares a las empleadas desde 1489 cuando comenzaron las primeras ventas de juros "de prestidos" o "al quitar" situados sobre las rentas regias ordinarias como forma de "deuda pública consolidada" emitida por la Corona para hacer frente a los gastos del asedio de Baza ante la imposibilidad de devolver con el dinero procedente de la cruzada los préstamos concertados con instituciones y particulares en $1489{ }^{61}$.

\footnotetext{
58 Original en AHNob, Frías, C. 1724, doc. 5. Copia de registro en AGS, RGS, marzo de 1491, f. 4

59 AFRM. Caja 98, leg. 1, doc. 22. Procedimiento de amortización del préstamo en QuintanILLA RASO y Blázquez Mayoral, La forja de una casa nobiliaria, pp 178-179. Ladero Quesada, La Hacienda Real de Castilla, 1369-1504, p. 226. Franco Silva, La fortuna y el poder, pp. 223-224.

60 Una excepción es el préstamo de 2.000.000 mrs realizado por el marqués de Cádiz a los reyes en 1489 con motivo del asedio de Baza, cuyo plazo de devolución quedó fijado en un año. CAÑAs GÁlvez, "Fray Hernando de Talavera", pp. 182-186.

61 Castillo Pintado, "Los juros de Castilla", pp. 43-46; Ladero Quesada, La Hacienda Real de Castilla, 1369-1504, pp. 225-227; GÁlvez GAMBERo, "Reforma y consolidación”, pp. 100-104.
} 
No obstante, en el caso del empréstito de Carrillo la venta era a perpetuidad: los reyes carecían de la posibilidad de cancelar las rentas entregadas mediante la restitución del principal, por lo que no se trataba en principio de cuantías redimibles por voluntad regia; además, la pensión anual entregada tampoco era stricto sensu equivalente al "interés" a percibir por el préstamo realizado. Es decir, todavía no aparecen los elementos característicos de los futuros juros "al quitar", aunque la venta de rentas realizada prefigura la mecánica arbitrada más adelante para incentivar la obtención de recursos financieros. Por otra parte, a tenor de la equivalencia de $600.000 \mathrm{mrs}$ de renta anual por los mil vasallos, señalada en la carta de finiquito de 1491, los $16.000 .000 \mathrm{mrs}$ del préstamo de Carrillo correspondían a la compra de 1.200.000 mrs de pensión anual. Esto significa que el precio de venta fijado por la Corona era de $13.333 \mathrm{mrs}$ por cada millar de mrs. La cantidad era superior a los 10.000-11.000 mrs al millar (que suponían intereses anuales del 10-9,09 \% sobre el dinero prestado) en los que quedaría fijado el precio de venta de los primeros juros "al quitar" en 148962, aunque resultaba inferior a los 15.000 mrs al millar establecidos para la compra por parte del cabildo de Toledo del juro sobre las tercias del arciprestazgo de Montalbán formalizada en 1482.

Al margen de estas diferencias, que distinguen claramente los juros "al quitar" del mecanismo empleado con anterioridad para amortizar el préstamo de Carrillo, el concierto negociado en 1483 establecía varias fases para el reintegro del dinero. En un primer momento, como garantía de cumplimiento del acuerdo, y hasta que la entrega de los 1.000 vasallos se hiciese efectiva, los reyes empeñaron a Carrillo la villa y fortaleza de Molina de Aragón y le concedieron una pensión anual de 600.000 mrs a percibir durante un trienio con cargo a las rentas ordinarias molinesas cobradas por la Corona ${ }^{63}$. Esta primera cláusula del acuerdo de 1483 responde a una lógica que conviene tener presente. Molina era señorío de los reyes, por lo que su empeño quizás podía realizarse en unas condiciones de mayor libertad que las ofrecidas por los territorios del realengo. Pero sobre todo, el linaje Carrillo-Acuña ya había ocupado anteriormente la tenencia de Molina y había cobrado rentas reales en su partido fiscal, por lo que contaba con bases de poder en un territorio estratégico dentro de línea política de aproximación a Aragón defendida por el linaje, además de con intereses económicos y capacidad logística. El arzobispo de Toledo Alfonso Carrillo ya había recibido del infante-rey don Alfonso en diciembre de 1467 la alcaidía de Molina de Aragón con 200.000 mrs de salario. Por su parte, su hijo Troilos Carrillo, primo de Alonso Carrillo, recibió en enero de 1468 otros $200.000 \mathrm{mrs}$ en juro de heredad situados sobre las alcabalas y portazgo de Molina y su tierra, así como las tercias reales de la villa ${ }^{64}$. Ya durante el reinado de Isabel I, y hasta al menos 1481, don Troilos ocuparía la tenencia de los alcázares de Molina y de la llamada "Torre de Aragón" desde la cual se controlaba el acceso al reino vecino. Además, había sido autorizado por los Reyes Católicos desde 1475 para cobrar las alcabalas, tercias,

\footnotetext{
62 Gálvez Gambero, "Reforma y consolidación”, pp. 103-104.

63 AFRM. Caja 98, leg. 1, doc. 22. La duración trienal de este empeño se explicita en las cuentas de Molina de Aragón de 1483-1484. AGS, CMC, $1^{\text {a }}$ ép., leg. 18, sin f.

64 Morales Muñız, Alfonso de Ávila, p. 292.
} 
diezmos y aduanas, y otros pechos y derechos de Molina, y fue perceptor hasta 1481 de parte de estas rentas en pago por la tenencia disfrutada ${ }^{65}$.

En efecto, el abono a Alonso Carrillo de las sumas consignadas con cargo a las rentas de Molina de Aragón y su tierra conforme al acuerdo alcanzado, mientras se fijaba la cesión de los 1.000 vasallos, fue efectivo durante el bienio 1483-1484. La cuenta de las alcabalas y tercias de la villa rendida por el recaudador mayor don Mose Asayol, recoge en 1483 el pago, por carta de libramiento dada en Madrid el 4 de febrero del mismo año, de 600.000 mrs a Carrillo, a repartir entre las rentas que desease: 100.000 mrs correspondían al sueldo por la tenencia de los alcázares; los 500.000 mrs restantes debía percibirlos "segund que fue capitulado con él que ge los librasen por tres años" en alusión al compromiso negociado con los reyes para redimir su préstamo. La cuenta de 1484 recoge pagos semejantes que de nuevo remiten al cumplimiento efectivo de lo acordado en $1483^{67}$. Por lo demás, la fecha de la carta de libramiento de los 600.000 mrs a pagar en 1483 (4 de febrero de 1483) confirma que el acuerdo económico al que llegaron los reyes con Carrillo estaba condicionado a la venta de Maqueda a Cárdenas oficializada, según se ha señalado, el día anterior (3 de febrero de 1483).

65 El 28 de julio de 1475 los reyes se dirigían a las autoridades y cobradores de las rentas de Molina ordenando pagar a Pedro Carrillo de Mendoza y a su hermano Íñigo López de Mendoza las cantidades que debían percibir con cargo a las alcabalas, tercias, diezmos, aduanas, pedidos, monedas, martiniegas, moneda forera y otros pechos y derechos de Molina y su tierra. Los interesados habían mostrado su recelo ante la posibilidad de que Troilos Carrillo, que tenía poder de los reyes para recaudar las rentas de Molina, quisiese "perturbar e enbargar las rentas e mrs e otras cosas que tyenen e poseen asy sytuados como en otra manera en esa dicha villa e su tierra". AHNob, Priego, C. 10, doc. 37. Traslado de la carta real en AHNob, Priego, C. 8, doc. 2. El mismo año 1475, el común de la tierra de Molina prestaba $50.000 \mathrm{mrs}$ a don Troilos, cuya restitución debería realizar Pedro del Castillo, receptor nombrado para cobrar las alcabalas y aduanas de la villa, que sin embargo puso impedimentos para el pago. AGS, RGS, enero de 1478, f. 174. Por otra parte, Troilos Carrillo es mencionado como alcaide de Molina en carta real dada el 16 de julio de 1478 desde Sevilla. AGS, RGS, julio de 1478, f. 80. La relación de cuenta de los pagos que debía realizar durante el bienio 1477-1478 el "facedor" Alonso González de Buitrago con cargo a las alcabalas, tercias, diezmos y aduanas, y otros pechos y derechos de Molina señala que, una vez pagados los $5.000 \mathrm{mrs}$ de su salario como receptor, $100.000 \mathrm{mrs}$ a Pedro de Córdoba para la tenencia de El Pardo, y 40.000 mrs por el juro de heredad que tenía situado en estas rentas Juan de Aguilera, con la cantidad restante debía acudir a Troilos Carrillo en pago por la tenencia de la villa de Molina de 1477-1478 y en adelante. Además, debería abonar, sin embargo de la "recepta" de don Troilos, otros $150.000 \mathrm{mrs}$ al Cardenal de España Pedro González de Mendoza por un juro que tenía situado en los diezmos y aduanas de Molina, concedido por la reina el 20 de septiembre de 1477. AGS, EMR, leg. 23, ff. 80-81. En 1479 la cuantía percibida por don Troilos Carrillo por la tenencia del alcázar y Torre de Aragón ascendía a 365.000 mrs. AGS, EMR, leg. 27, f. 83. Una pesquisa del precio y beneficiarios por menor de las rentas de Molina de 1477-1479, enmarcada en el contexto de las declaratorias de Toledo, recoge de nuevo pagos de rentas por menor de Molina y su tierra entregados al receptor de don Troilos Carrillo. AGS, EH, leg. 2, f. 285. Finalmente, en 1481 todavía percibía don Troilos 200.000 mrs por la tenencia de los alcázares de Molina y la Torre de Aragón con cargo a las rentas molinesas. AGS, EMR, leg. 31, ff. 184-185.

66 Se sumaban a estas cantidades otros $70.000 \mathrm{mrs}$ correspondientes a su acostamiento, librados el mismo día.

${ }^{67}$ Cuentas de Molina de Aragón de 1483-1484 en AGS, CMC, $1^{\text {a }}$ ép., leg. 18, sin f. 


\subsection{El nuevo acuerdo de 1485}

Por motivos desconocidos, las condiciones de redención del préstamo entregado por Carrillo en 1483 cambiaron en 1485. La carta de finiquito del empréstito expedida por el guarda mayor en 1491 alude de manera poco precisa a ciertas "dificultades que ocurrieron en el cunplimiento de lo contenido en la dicha capitulaçión”, quizás como consecuencia del mayor esfuerzo asociado al conflicto bélico, de la necesidad de poner a disposición de la Corona todos los recursos financieros posibles, o de problemas de carácter logístico relacionados con la cesión de rentas y vasallos. Sea como fuere, estos problemas dieron lugar a la negociación de un segundo acuerdo de amortización del préstamo consensuado entre los reyes y el guarda mayor firmado en Sevilla el 4 de febrero de 1485, que puede ser reconstruido en algunos de sus detalles, y que pese a los retos que implicaba en el corto plazo, abrió a la postre nuevas "ventanas de oportunidad" al guarda mayor que le permitirían diversificar los beneficios obtenidos ${ }^{68}$.

Las principales condiciones para cancelar el préstamo de 1483 concertadas en esta nueva capitulación se referían a los siguientes aspectos:

1) Se establecía un reparto por mitades de los mil vasallos y de los $600.000 \mathrm{mrs}$ en rentas acordados como compensación en 1483. De este modo, 500 vasallos serían satisfechos mediante la cesión a Carrillo de la jurisdicción de la villa de Caracena y su tierra -en el límite de las actuales provincias de Soria, Segovia y Guadalajara-, rentas, pechos y derechos, junto al lugar de Inés y su fortaleza, vasallos y rentas; los $300.000 \mathrm{mrs}$ de renta anual (la mitad de los $600.000 \mathrm{mrs}$ en rentas inicialmente asignados en 1483) se compensarían con un juro de heredad por este valor situado sobre las alcabalas y tercias de Caracena ${ }^{69}$. Presumiblemente, esta había sido una de las piezas codiciadas desde el principio por Carrillo a la hora de negociar la venta de Maqueda con Cárdenas y acordar su vinculación con un préstamo a los monarcas para la guerra de Granada.

2) Una vez notificada ante escribano público la entrega a Alonso Carrillo de la villa de Caracena y del lugar de Inés con su torre, el guarda mayor se comprometía a devolver a la Corona las prendas que tenía como seguridad. De esta forma, la villa de Molina, su alcázar y la "Torre de Aragón" serían entregados a Juan de Torres, vecino de Soria, para que como representante de los monarcas tomara posesión de los bienes empeñados a Carrillo previamente ${ }^{70}$.

3) La otra mitad que restaba para amortizar el préstamo (500 vasallos y $300.000 \mathrm{mrs}$ de renta) sería abonada al guarda mayor en censos perpetuos sobre heredades situadas

\footnotetext{
68 La fecha del nuevo acuerdo se menciona en AGS, RGS, marzo de 1485, f. 28. Cit. Quintanilla Raso y BlázQuez Mayoral La forja de una casa nobiliaria, p. 179.

69 AFRM, Caja 98, leg. 1, doc. 22. AGS, RGS, marzo de 1485, f. 28.

70 AGS, RGS, marzo de 1485, f. 28.
} 
en Sevilla, su tierra y arzobispado por valor de 600.000 mrs anuales, "con los títulos e derechos que Sus Altezas tenían a ello"

\subsection{La cesión de Caracena, Inés y sus rentas}

El nuevo acuerdo concertado respondía a los intereses que Carrillo y su linaje tenían en dos espacios muy diferentes. Por un lado, aseguraba su consolidación señorial en el territorio estratégico de la frontera con Aragón; por otro, garantizaba la proyección de su linaje en el ámbito hispalense. No obstante, este segundo acuerdo también tuvo que hacer frente a complicaciones de modo que, para asegurar su cumplimiento, Carrillo negoció nuevas cláusulas con los reyes. En el documento de 4 de febrero de 1485 se fijaban seis meses de plazo para que los monarcas formalizasen la entrega de los mil vasallos y $600.000 \mathrm{mrs}$ de renta bajo las nuevas condiciones. Entre estas últimas se incluía 1) la compensación por los vasallos y rentas que faltasen en Caracena y el lugar de Inés, una vez hecha una pesquisa para verificar su número y cuantía, respectivamente; 2) la entrega de la sentencia de confiscación dada por los reyes contra Martín [Fernández] de Tovar, anterior señor de Caracena, desposeído de la villa por el apoyo prestado a Portugal durante el conflicto sucesorio ${ }^{72} ; 3$ ) el saneamiento del derecho que Leonor de Villena, mujer de Martín de Tovar, pudiera tener sobre el lugar de Inés en razón de su dote y arras; y 4) la expedición de una nueva carta de seguridad de los reyes "en que seguran e prometen que los dichos vasallos le serán çiertos e sanos en todo tienpo". Como se observa, estas condiciones concedían un plus de garantías jurídicas a la operación en la medida en que, además del compromiso de la Corona, se aseguraba la defensa de los derechos adquiridos por Carrillo frente a reclamaciones de terceros, como los hijos de Martín de Tovar y Leonor de Villena.

El incumplimiento de cualquiera de estas condiciones, una vez transcurridos los seis meses de plazo fijados para la entrega de vasallos y rentas, llevaría aparejado 1) la restitución a Carrillo del dominio sobre la villa de Molina, su alcázar y la "Torre de Aragón", previamente cedida a Juan de Torres; 2) la entrega al guarda mayor del corregimiento de Molina; 3) el pago de 100.000 mrs anuales por la tenencia de Molina, "para que lo tenga todo por prendas e seguridad de los dichos vasallos que asy faltaren en la dicha Caraçena e Hynés". Posteriormente, una vez cumplida la entrega de todos los vasallos, las nuevas prendas tomadas volverían a poder de la Corona. Sin embargo, para reforzar la seguridad de la operación, y ante la hipotética negativa de Juan de Torres a devolver la fortaleza de Molina y la "Torre de Aragón" - algo a lo que Torres debía comprometerse con Carrillo mediante pleito-homenaje-, el guarda mayor exigió como

\footnotetext{
AFRM, Caja 98, leg. 1, doc. 22.

72 El linaje Tovar tenía el señorío de Caracena y Cevico desde el 8 de junio de 1368, fecha en la cual Enrique II concedía a su guarda mayor Sancho Fernández de Tovar la jurisdicción de ambas villas. Sobre el linaje Tovar, y la figura de Juan o Martín de Tovar ver Franco SiLva, "Señores y campesinos en tierras de Soria", pp. 518-520.
} 
garantía la entrega de una nueva fortaleza en prenda. La cláusula solicitada volvió a involucrar a Cárdenas, que cruzaba de nuevo sus intereses con los de Alonso Carrillo. El 15 de mayo de 1485 los reyes permitían al Comendador Mayor de León hacer pleito-homenaje a Carrillo por la tenencia de la fortaleza y alcázares de Carmona, según había solicitado este último, aunque el traspaso solo sería efectivo en caso de incumplimiento del nuevo acuerdo suscrito con los monarcas. También se autorizaba a Cárdenas a expedir en favor del guarda mayor carta de seguridad sellada con su sello como compromiso privado de cumplimiento efectivo de lo estipulado por los reyes. Finalmente, los monarcas ordenaban levantar cualquier pleito-homenaje que pudiera haber realizado previamente el Comendador Mayor de León sobre la tenencia de Carmona, cuya cesión en el supuesto considerado duraría hasta que el nuevo acuerdo alcanzase pleno cumplimiento o le fuese restituido a Carrillo el alcázar de Molina ${ }^{73}$.

En efecto, el protocolo fijado para la entrega a Carrillo de la villa de Caracena y del lugar de Inés, con sus rentas, siguió los cauces establecidos. El 2 de febrero de 1485 -dos días antes de que el nuevo acuerdo de amortización del préstamo quedara suscrito- los reyes habían dado, a petición del bachiller Pedro Díaz de la Torre, procurador fiscal de los monarcas y procurador mayor de la justicia regia y "del ynterese público de nuestros regnos", una carta de emplazamiento desde Sevilla para que Martín Fernández de Tovar, anteriormente llamado Juan de Tovar, compareciese en un plazo de treinta días de manera personal ante el Consejo Real para defender su derecho y presentar alegaciones ante las graves acusaciones interpuestas por el bachiller de la Torre que habían determinado la confiscación de todos sus bienes - entre ellos el señorío de Caracenapor la ayuda prestada en 1478 al arzobispo de Toledo Alonso Carrillo de Acuña para la defensa de Alcalá de Henares a favor de la causa de Alfonso V de Portugal ${ }^{74}$. Se trataba de un formalismo sin el cual no podía ser pronunciada la sentencia condenatoria que desposeía definitivamente a Martín de Tovar de su señorío sobre Caracena e Inés -expedida finalmente el 20 de junio de $1489^{75}$-, y exigida como garantía por Carrillo en la capitulación suscrita dos días después (4 de febrero de 1485).

Por otra parte, la cesión de Caracena e Inés requería, tal y como se ha señalado, de la realización de una pesquisa que permitiera fijar compensaciones económicas en caso de que el número de vasallos de las jurisdicciones entregadas fuera menor a los 500 vasallos señalados en el acuerdo de amortización renegociado en febrero de 1485. Para ello, los reyes comisionaron antes del 4 de marzo a su aposentador Diego de Valladolid con el

\footnotetext{
73 AGS, RGS, marzo de 1485, f. 28. Cit. Quintanilla Raso y BlázQuez Mayoral, La forja de una casa nobiliaria, p. 179.

74 AGS, RGS, febrero de 1485, f. 250. Juan de Tovar ya había recibido un perdón de los reyes el 10 de diciembre de 1476 por su militancia en el bando portugués durante el conflicto sucesorio. Sin embargo su nuevo respaldo a la invasión portuguesa en 1478, prestando apoyo al arzobispo de Toledo Alonso Carrillo de Acuña mediante la ocupación de Alcalá de Henares, y la derrota de su bando en la contienda, llevaron a los reyes a ser menos benignos en esta segunda ocasión: Juan de Tovar sería sentenciado a muerte y a la pérdida total de sus señoríos, confiscados para la Corona. Franco Silva, "Señores y campesinos en tierras de Soria", pp. 519-520.

75 Franco Silva, "Señores y campesinos en tierras de Soria”, p. 520.
} 
mandato de contar los vasallos del lugar de Inés y de averiguar "lo que renta el dicho logar asy de lo que pertenesçía al señorío como a nos" "76. Con la finalidad de dotar el proceso de averiguación de más garantías para las dos partes, junto Diego de Valladolid también intervendría en la pesquisa Fernando de Córdoba, criado de Carrillo $^{77}$. Más adelante, el 4 de marzo de 1485, los reyes -a petición del guarda mayor- conminaban a su aposentador a tomar el lugar de Inés y su fortaleza, y a entregar su posesión a Carrillo, levantando para ello cualquier pleito-homenaje previo que pudiera afectar a la tenencia ${ }^{78}$. Al cabo, tres días más tarde, el 7 de marzo, los monarcas ordenaban en sendas cartas al concejo de Caracena y a su alcaide Juan de Cuero traspasar al guarda mayor la jurisdicción de Caracena y su término, así como su fortaleza ${ }^{79}$.

No obstante, la cesión de la jurisdicción de Caracena e Inés no sería suficiente. El resultado de la averiguación, realizada a lo largo de 1485, arrojó un total de 377 vasallos y medio contabilizados en ambas localidades y sus tierras. El valor de sus rentas ascendía, por un lado, a $107.678 \mathrm{mrs}$ anuales correspondientes a las rentas, pechos, derechos, paso de ganados, huertas, casas, terrazgos y tercias pertenecientes al señorío de Caracena y sus aldeas de Madruédano, Santa María del Val y Adanta, y al lugar de Inés; y por otro, a $114.500 \mathrm{mrs}$ correspondientes a las alcabalas cobradas en este espacio. Esta última cantidad le fue situada a Alonso Carrillo para cubrir parte de los 300.000 mrs de renta cuya cesión estipulaba el segundo acuerdo. No obstante, la emisión de las cartas de privilegio -tanto de la referida a la jurisdicción de Caracena e Inés, como las correspondientes al juro de 114.500 mrs y a la cesión de las tercias de pan, vino y ganados de Caracena- todavía hubo de esperar hasta fines de marzo de $1491^{80}$, por lo que la cesión de rentas y vasallos de ambas jurisdicciones no alcanzó plena seguridad jurídica. ¿Acaso se trataba de una "carta" que los reyes y sus agentes se guardaban para afrontar las negociaciones con Carrillo desde una posición de mayor fortaleza? Sea como fuere, explica la situación de provisionalidad en el cumplimiento íntegro del acuerdo que se observa entre 1485 y 1491, mientras se resolvían los problemas generados por la entrega de estos y otros vasallos y bienes, y la aplicación efectiva de algunas de las cláusulas de seguridad reconocidas en febrero de 1485.

A tenor de la pesquisa, restaban por lo tanto 122 vasallos y medio para cumplir con los 500 vasallos comprometidos por los reyes, y $77.822 \mathrm{mrs}$ de renta para terminar de cubrir los 300.000 mrs anuales fijados en la nueva capitulación. Por lo tanto, en un tercer acuerdo cuya fecha desconocemos, Carrillo concertó con los monarcas las indemnizaciones con las que se terminaría de cubrir la mitad de la amortización del préstamo: 1) para compensar los mrs de renta que faltaban hasta los $300.000 \mathrm{mrs}$ fijados, le serían entregados 80.000 mrs en tributos a percibir en Sevilla y su tierra; 2) en

\footnotetext{
6 AGS, RGS, marzo de 1485, f. 157.

AFRM, Caja 98, leg. 1, doc. 22.

AGS, RGS, marzo de 1485, f. 157.

79 AGS, RGS, marzo de 1485, f. 156. Según la orden regia la entrega de la fortaleza se consumaría una vez requerido su alcaide por el aposentador Diego de Valladolid. AGS, RGS, marzo de 1485, f. 185.

80 Privilegio de cesión de la jurisdicción de Caracena e Inés (1491-3-26. Sevilla). AHNob, Frías, C. 1724, doc. 5. AGS, RGS, marzo de 1491, f. 4. Juro de 114.500 mrs situados en las alcabalas de Caracena e Inés, y cesión de las tercias (1491-3-24. Sevilla). AHNob, Frías, C. 1715, doc. 1.
} 
compensación por los 122 vasallos y medio que faltaban -tasados a $8.000 \mathrm{mrs} / \mathrm{vasallo}$, lo que hacía un total de $980.000 \mathrm{mrs}$ - el guarda mayor recibiría $100.000 \mathrm{mrs}$ de juro anuales situados en las alcabalas de Alcalá de Guadaíra, ubicada en el partido fiscal de Jerez de la Frontera. Ello suponía establecer una equivalencia de $9.800 \mathrm{mrs}$ al millar por el juro cedido, por lo que su valor era algo inferior al precio de venta fijado para los juros “al quitar” emitidos desde 1489 (10.000 y 11.000 mrs al millar) ${ }^{81}$.

La contabilidad de las alcabalas y tercias del partido de los señoríos del obispado de Sigüenza -donde se localizaba a efectos recaudatorios Caracena- registra algunos de los pagos realizados al guarda mayor vinculados con el segundo acuerdo. Desde 1485 y hasta 1495 las cuentas rendidas y las previsiones de ingresos y gastos incorporan suspensiones anuales de $103.000 \mathrm{mrs}$, autorizadas por los contadores mayores a los recaudadores mayores de la circunscripción, correspondientes a las alcabalas y tercias de Caracena cedidas a Carrillo ${ }^{82}$. La falta de concordancia entre los $114.500 \mathrm{mrs}$ situados en las alcabalas de la villa de acuerdo con la pesquisa, y la cuantía anual asentada como suspensión en los señoríos del obispado de Sigüenza no ha podido ser explicada. Por el contrario, las previsiones de gasto con cargo a las rentas de Molina de Aragón y su tierra elaboradas por los contadores reales para 1485 y 1486 verifican el cumplimiento exacto de la capitulación en este punto.

A los 100.000 mrs correspondientes a la tenencia del alcázar de Molina, que el guarda mayor siguió percibiendo en 1485, se añaden dos pagos con cargo a las rentas molinesas a favor de Carrillo, vinculados con la devolución del empréstito, que difieren de los registrados en las cuentas de 1483-1484 ${ }^{83}$. El primero, de $79.577 \mathrm{mrs}$, era la parte desembargada el 26 de septiembre de 1485 de los 200.000 mrs (parte a su vez de 300.000 mrs "que se le avían de dar de renta en Caraçena") que debía percibir en cuenta de la suma de 500.000 mrs reconocida en el acuerdo inicial de restitución del préstamo. De esta última cuantía $300.000 \mathrm{mrs}$ fueron librados a favor del tesorero de la reina Ruy López de Toledo, para el mantenimiento del rey de Granada [Muhammad XII Boabdil], en poder de los reyes ${ }^{84}$. Un segundo pago en favor de Carrillo, de 16.732

\footnotetext{
81 AFRM, Caja 98, leg. 1, doc. 22.

82 Cuentas de las alcabalas y tercias de los señoríos del obispado de Sigüenza de 1485-1486 rendidas por el recaudador mayor Juan del Castillo con mención a la suspensión de 103.500 mrs por las alcabalas

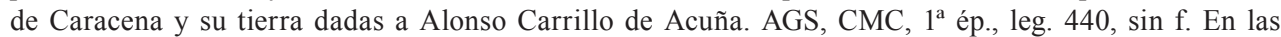
relaciones de cuenta del mismo partido de los señoríos del obispado de Sigüenza de 1491 y $1493-1494$ se recoge la misma suspensión de las rentas concedidas a Alonso Carrillo en Caracena. AGS, EMR, leg. 50, f. 77; AGS, EMR, leg. 51, f. 61; AGS, EMR, leg g. 52-1, f. 184; AGS, EMR, leg. 52-2, f. 181; AGS, EMR, leg. 53, f. 219-220; AGS, EMR, leg. 55, ff. 334-335. También la cuenta rendida de 1495 recoge las

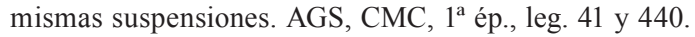

83 Además de otros pagos. Alonso Carrillo debía percibir con cargo a las alcabalas y tercias de Molina de Aragón de 148570.000 mrs de su acostamiento y 10.200 mrs de su ración y quitación como guarda mayor. AGS, EMR, leg. 39, ff. 403 y 405.

84 En efecto, esta cuantía fue abonada a Ruy López de Toledo. En su cargo o ingreso de tesorería de 1485 un asiento señala lo siguiente: "Fueron librados al dicho thesorero por otro mandamiento de Sus Altezas fecho a [en blanco] días de [en blanco] del dicho año CCCU mrs que le fueron librados en el recabdador de Molina para el mantenimiento del rey de Granada". AGS, CMC, $1^{a}$ ép., leg. 106, sin f.
} 
mrs, correspondía a una parte de 79.822 mrs que debía recibir en 1486 "en conplimiento de las 300.000 mrs que se le devían de dar en Caraçena" ${ }^{5}$. En efecto, esta última cifra concuerda con la diferencia apuntada entre el valor de las rentas de Caracena e Inés averiguado en la pesquisa, y los mencionados $300.000 \mathrm{mrs}$ de renta.

Estos asientos contables se repiten de forma muy semejante en la previsión de los gastos a abonar con cargo a las alcabalas y tercias de Molina de 1486, y ponen en evidencia la articulación de mecanismos provisionales de compensación por parte de los oficiales hacendísticos que permitieron afrontar las obligaciones económicas de los reyes con Carrillo $^{86}$. No hacerlo podía comprometer la petición de nuevos recursos a miembros de la sociedad política y minar la confianza de los inversores en un contexto definido por las necesidades de financiación del erario regio.

La misma transitoriedad en el cumplimiento completo de las condiciones de amortización incluidas en el acuerdo de 1485 también se desprende de otros datos. Pese a que la cesión de la jurisdicción de Caracena y de sus rentas debía haberse hecho efectiva una vez finalizada la pesquisa, ya se ha señalado que la carta de privilegio real no fue expedida hasta marzo de 1491. Mientras tanto, tal y como preveía la capitulación, Alonso Carrillo siguió teniendo bajo su poder la tenencia de la fortaleza de Molina: entre 1485 y al menos 1492 continuó percibiendo los 100.000 mrs anuales de salario con cargo a las alcabalas y tercias de la villa y su tierra ${ }^{87}$, que desaparecen de la contabilidad tras la cesión de la tenencia a don Juan de Silva, conde de Cifuentes ordenada por los reyes el 23 de junio de $1492^{88}$. Por otro lado, según establecía el segundo concierto alcanzado con los reyes, Carrillo fue nombrado corregidor de Molina de Aragón, probablemente al no haberse terminado de formalizar la cesión de Caracena y de los $300.000 \mathrm{mrs}$ en los seis meses de plazo fijados en el acuerdo. Sin embargo, el guarda mayor ya no ocupaba el corregimiento a comienzos de 1488, quizás a raíz de las denuncias presentadas desde 1485 por el común de la tierra de Molina ante la rapacidad impositiva con la que

\footnotetext{
85 Sí percibió, sin embargo, los 10.200 mrs correspondientes a su ración y quitación por guarda mayor. AGS, EMR, leg. 39, ff. 403 y 405 . Existen otras dos previsiones de ingresos y gastos, probablemente previas a esta, menos completas en AGS, EMR, leg. 39, ff. 237-238.

86 Además del pago de $100.000 \mathrm{mrs}$ por la tenencia del alcázar de Molina, los $70.000 \mathrm{mrs}$ de su acostamiento, y $4.900 \mathrm{mrs}$ correspondientes a parte de los $10.200 \mathrm{mrs}$ que debía percibir de su ración y quitación como guarda mayor, Alonso Carrillo debía cobrar con cargo a las alcabalas y tercias de Molina de Aragón de $148663.100 \mathrm{mrs}$ correspondientes a los $79.577 \mathrm{mrs}$ desembargados el 26 de septiembre de 1485 "de estas CCU mrs que ovo de aver en cunplimiento de las CCCU mrs que se le avían de dar de renta en Caraçena". AGS, EMR, leg. 42, ff. 173-174. Existe otra previsión previa a esta relación de cuenta menos completa en AGS, EMR, leg. 39, ff. 237. Las cuentas de Molina posteriores a 1486 ya no recogen ningún pago derivado de acuerdo de compensación por el préstamo de los $16.000 .000 \mathrm{mrs}$.

87 AGS, EMR, leg. 47, f. 160; leg. 48, f. 131; leg. 49, ff. 204-205. Ladero Quesada, "La receptoría y pagaduría", pp. 467 y $486-487$.

88 El 23 de junio de 1492 los reyes ordenaban a Alonso Carrillo entregar la fortaleza de Molina a don Juan de Silva. AGS, RGS, junio de 1492, f. 78-1. La cuenta de las alcabalas, tercias y otros pechos y derechos de Molina de 1495 rendida por su recaudador mayor Alonso Gutiérrez de Madrid ya incluye un pago de 120.000 mrs librado el 8 de abril de 1495 a favor de don Juan de Silva, conde de Cifuentes, por la tenencia de la fortaleza de Molina (100.000 mrs) más 20.000 mrs que se le debían de la tenencia de 1494. AGS, CMC, $1^{a}$ ép., leg. 18 y 41, sin f.
} 
había actuado, atendidas favorablemente por los reyes ${ }^{89}$. Esta actitud de Carrillo con sus vasallos molineses volvería a repetirse años más tarde con los vecinos de Caracena, una vez consumada la cesión de su jurisdicción: los abusos, y desafueros cometidos por el guarda mayor eran denunciados en 1498 ante los reyes ${ }^{90}$.

\subsection{Los censos de Sevilla y la renegociación de nuevas compensaciones económicas}

Si bien la cesión de Caracena e Inés, y de los 300.000 mrs de renta situados en las rentas de ambas localidades y sus tierras, generó esta compleja problemática hasta su ejecución definitiva en 1491, para el cumplimiento de la otra parte del segundo acuerdo de amortización del préstamo, según había quedado concertado en febrero de 1485 , Carrillo tuvo que sortear nuevas trabas que dieron lugar a una nueva renegociación -la cuarta- de los compromisos inicialmente suscritos por los reyes. No obstante, el nuevo acuerdo resultaría a la larga beneficioso para el guarda mayor como parte de sus estrategias de consolidación patrimonial y política en el entorno hispalense y en el valle medio del Tajo, por lo que Carrillo pudo hacer de la necesidad virtud.

Los 600.000 mrs anuales en censos perpetuos sobre heredades situadas en Sevilla y su arzobispado fijados como valor por los 500 vasallos y $300.000 \mathrm{mrs}$ (correspondientes a la otra mitad de la cuantía destinada a amortizar el préstamo), fueron efectivamente entregados a Carrillo. A esta suma se añadió la cesión al guarda mayor realizada por parte de los reyes el 4 de marzo de 1485 "acatando los muchos e buenos e leales serviçios" ofrecidos, de la fortaleza de Lebrija, perteneciente a la ciudad de Sevilla, junto a 100.000 mrs de salario a pagar con cargo a las rentas locales hispalenses ${ }^{91}$. Todo

89 El 4 de julio de 1485 los reyes daban un requerimiento emplazando al corregidor y alcaide de Molina Alonso Carrillo para que devolviese al común de la tierra de Molina los 20.000 mrs maravedíes repartidos en dos años injustamente, por medio de la fuerza y sin contar con licencia regia "tenyendo la dicha justiçia e fortaleza de la dicha villa", además del salario pagado desde tiempo inmemorial por el corregimiento de la villa. De mantenerse el reparto sería necesario poner "ynposyçión nueva". AGS, RGS, julio de 1485, f. 82. El 18 de enero de 1488 los reyes comisionaban al licenciado Pedro Sánchez del Castillo, designado previamente como juez para tomar la residencia de Alonso Carrillo y de sus oficiales, para que resolviese - tras haber remitido su juicio de residencia al Consejo Real- la disputa por ciertas cuantías tomadas injustamente por Carrillo a algunos vecinos de la villa y el común de su tierra "las quales non se pudieron averiguar syn ser llamadas e oydas las partes". Una vez oídas ambas partes, y comprobada la veracidad de los hechos denunciados, se le autorizaba para ejecutar en los bienes de Carrillo las sumas tomadas. AGS, RGS, enero de 1488, f. 144. Dos días antes (16 de enero de 1488) se había remitido carta real al mismo licenciado Sánchez del Castillo en la que se explicitaban los desafueros cometidos por Carrillo, y ordenaban su cese: el común y tierra de la villa de Molina había denunciado a Carrillo, alcaide de los alcázares, por el repartimiento de cierta paja y leña "que por fuerça e contra su voluntad de los vezinos de la dicha tierra les costriñen e apremian a que ge lo den syn les pagar cosa alguna”. AGS, RGS, enero de 1488 , f. 135.

90 Franco Silva, "Señores y campesinos en tierras de Soria”, pp. 526-531.

91 AGS, RGS, marzo de 1485, f. 155 . El 7 de marzo de 1485 los reyes ordenaban a Garcilaso de la Vega, caballero "de nuestra casa" y alcaide de Lebrija, entregar la fortaleza a Alonso Carrillo. AGS, RGS, marzo de 1485, f. 158. El 8 de julio de 1485 fue necesario expedir una sobrecarta en la que los reyes ordenaban el abono a Alonso Carrillo del salario de 100.000 mrs por la tenencia de Lebrija, ya que este último 
apunta a que la tenencia lebrijana, permutada con Diego López de Haro desde 1488 por la tenencia de la fortaleza de Alcalá de Guadaíra que este ocupaba ${ }^{92}$, también formaba parte de las garantías acordadas para la redención del préstamo ${ }^{93}$, o bien era una forma que los reyes tenían de mostrar su disposición a cumplir con lo acordado y compensar la demora en hacer efectivas las capitulaciones.

Sea como fuere, parece claro que el guarda mayor aspiraba a consolidar un polo de poder en el ámbito hispalense que se sumaba a sus pretensiones señoriales en la frontera de Aragón, lo que constata la dispersión geográfica de los intereses del noble. Esta estrategia también explicaría el interés de Carrillo en fijar en Sevilla el cobro de los censos sobre los bienes inmuebles, la percepción de rentas en Alcalá de Guadaíra -cuya fortaleza controlaba desde 1488- y el compromiso de cesión de la tenencia de los alcázares de

había denunciado su impago por parte del cabildo de Sevilla. AGS, RGS, julio de 1485, f. 59. La toma de posesión debió efectuarse el 3 de abril, motivo por el cual la ciudad de Sevilla se mostró remisa a abonar la totalidad de su salario anual a Carrillo. Finalmente, dando cumplimiento a la sobrecarta enviada por los reyes, el 2 de noviembre de 1485 el cabildo hispalense emitía un libramiento a su mayordomo Juan de Sevilla ordenando el pago con cargo a las imposiciones arrendadas desde el 1 de enero de 1485 de $100.000 \mathrm{mrs}$ a Alonso Carrillo, alcaide de Lebrija. Kirschberg SchencK, Catálogo de los papeles del Mayordomazgo del siglo XV. VI (1475-1488), doc. 6460, p. 290. Durante el bienio 1486-1487 los 100.000 mrs de la tenencia fueron librados sin problemas (libramientos de 27 de enero de 1486 y de 19 de enero de 1487). Kirschberg Schenck, Catálogo de los papeles del Mayordomazgo del siglo XV. VI (1475-1488), docs. 6577,6649 , pp. 315 y 332 .

92 La cédula regia ordenando la permuta de las tenencias de las fortalezas de Alcalá de Guadaíra y Lebrija, con los 100.000 mrs de tenencia anual, fue expedida en Sevilla el 21 de febrero de 1488. La orden se hizo efectiva el 17 de abril de 1488, fecha en la cual García Fernández Hermoso, jurado y escribano público de Alcalá de Guadaíra, daba fe de la comparecencia de Alonso Carrillo ante Juan de Proaño, alcaide de la fortaleza de Alcalá de Guadaíra en nombre de Diego López de Haro, con una carta de los reyes y otra de Diego López de Haro, ordenando al alcaide entregar el castillo a Carrillo. Posteriormente, el 17 de mayo de 1488 se notificaba a Alfonso García de Laredo, lugarteniente del escribano mayor del cabildo de Sevilla, y a Juan de Sevilla, mayordomo del cabildo, la orden de pagar a Diego López de Haro únicamente $44.582 \mathrm{mrs}$ y 4 cornados como salario por la tenencia desde el 1 de enero de 1488 hasta el 17 de abril del mismo año, fecha esta última en la cual la tenencia de Alcalá de Guadaíra había pasado a poder de Alonso Carrillo. A partir de esta fecha la tenencia de Lebrija, disfrutada previamente por Carrillo, pasó a manos de Diego López de Haro, con los $100.000 \mathrm{mrs}$ de su salario. Aunque inicialmente Carrillo se negó a prestar juramento de pleito-homenaje a la ciudad de Sevilla, como propietaria de la fortaleza, los reyes le conminaron a hacerlo el 14 de junio de 1488, con el compromiso de no acoger malhechores. El 30 de junio le prohibían, además, entregar la fortaleza por orden de la ciudad sin contar con el mandato regio. Hay libramientos del pago a Carrillo de su salario de $100.000 \mathrm{mrs}$ como tenente en 1489 (6 de febrero de 1489), 1490 (3 de febrero de 1490), 1494 y 1495 (14 de enero de 1495). KirschBerg SCHENCK, Catálogo de los papeles del Mayordomazgo del siglo XV. VI (1475-1488), docs. 6787, 6819, 6862 у 6949, pp. 358, 362, 370 y 389. Kirschberg SchencK, Catálogo de los papeles del Mayordomazgo del siglo XV. VII (1489-1504), docs. 7707 y 8090, pp. 36 y 119. García Fitz, El castillo de Alcalá de Guadaíra, docs. $188,190-200$ y 207, pp. 439-448 y 453-454. Según carta real de 20 de septiembre de 1492 el guarda mayor había denunciado que "a cabsa que en ella no ay aposentamiento donde se pueda aposentar, no está en ella". Para compensarle por ello, ya el 20 de marzo de 1491 los reyes habían ordenado al concejo de Sevilla darle posada gratuita. García Fitz, El castillo de Alcalá de Guadaíra, docs. 202 y 204, pp. 449-450.

93 La carta real de 15 de marzo de 1485 explicita la entrega a Carrillo "de la dicha fortaleza de Lebrixa e la casa que le han de dar en Sevilla" vinculándola con la amortización del préstamo. AGS, RGS, marzo de 1485 , f. 28. 
Carmona, como parte de las seguridades exigidas ante un posible incumplimiento del acuerdo de amortización renegociado con los monarcas en febrero de 1485. A todos estos elementos se uniría, una vez redimido el préstamo en 1491, la concesión el 19 de agosto de 1491 del oficio de veinticuatría que ocupaba en Sevilla el difunto Pedro Mejías, y la entrega de la fortaleza de Santa Olalla de la cual este último había sido alcaide ${ }^{94}$. Con esta merced el guarda mayor introducía una cuña en el corazón del poder municipal de Sevilla, que afianzaba su posición política en el entorno hispalense: ambos oficios -la tenencia de Alcalá de Guadaíra y la veinticuatría- serían legados posteriormente a su hijo Pedro Suárez de Castilla en febrero de $1495^{95}$.

El cobro de los censos entregados a Carrillo en Sevilla como parte de la amortización del empréstito de 1483 tampoco estuvo exento de problemas. Una vez efectuado el traspaso de los $600.000 \mathrm{mrs}$ de renta anual fijados en el acuerdo de febrero de 1485, el guarda mayor denunció que parte de estos censos y tributos eran "inciertos", es decir, no ofrecían garantías de cobro. En otros casos, el precio tasado por los censos era mayor "de lo que comúnmente valían en la dicha çibdad de Sevilla", lo que exigió examinar los contratos y títulos para conocer "el verdadero e justo valor que valían" Más allá del interés del dato como constatación indirecta de la existencia de un mercado de capitales privados en Sevilla operando con total normalidad en la década de 1480, y de la fijación de "precios" de renta variables en función del tipo de "producto", ambas circunstancias penalizaban a Carrillo. Para solventarlas no tuvo más remedio que renegociar una vez más con los reyes mecanismos de indemnización, sustanciados en los siguientes puntos: 1) la cesión de $595.000 \mathrm{mrs}$ en tributos y censos en de Sevilla y su tierra; 2) la entrega de 67.000 mrs anuales de juro situados en ciertas rentas de Valdemoro e Illescas; y 3) el libramiento de 400.000 mrs en dinero líquido con cargo a los recursos del erario regio en un único pago ${ }^{97}$.

Estas nuevas cláusulas conviene examinarlas con detalle, porque aportan nuevas claves de la lógica que regía el acuerdo renegociado en función de los intereses del guarda mayor y de los condicionamientos impuestos por el contexto sociopolítico del momento. En primer lugar, todo parece indicar que los censos y tributos "inciertos" sobre bienes inmuebles y heredades entregados por la Corona a Carrillo procedían de bienes confiscados por la Inquisición a judeoconversos sevillanos, que después no pudieron ser cobrados. Así lo verifican varios datos. En primer lugar, la mención, incluida en el finiquito por la amortización del préstamo expedido en abril de 1491, a cierta carta de los reyes dada al guarda mayor que incorporaba las sentencias y condenas interpuestas contra las personas a las que se habían confiscado para "la cámara e fisco de Sus

\footnotetext{
94 Kirschberg Schenck, Catálogo de los papeles del Mayordomazgo del siglo XV. VII (1489-1504), doc. 7811, p. 57.

95 El 22 de febrero de 1495 los reyes entregaban como merced a Pedro Suárez de Castilla la tenencia de Alcalá de Guadaíra y la veinticuatría en el concejo de Sevilla que venía disfrutando su padre Alonso Carrillo, previa renuncia de este último. AGS, RGS, febrero de 1495, f. 54. García Fitz, El castillo de Alcalá de Guadaíra, doc. 210, pp. 456-457.

96 AFRM, Caja 98, leg. 1, doc. 22.

${ }_{97}$ AFRM, Caja 98, leg. 1, doc. 22.
} 
Altezas" los bienes raíces y heredamientos sobre los cuales se cobraban los tributos traspasados a Carrillo ${ }^{98}$. Por otra parte, el 7 de marzo de 1485 -apenas un mes después de la suscripción del segundo acuerdo para la amortización del préstamo- los monarcas donaban a Carrillo por carta dada en Carmona unas casas situadas en la collación de San Isidoro de Sevilla confiscadas para la "cámara y fisco" regio a Juan de Sevilla, mayordomo que había sido de la ciudad hispalense, "por quanto [...] fue declarado por hereje", con las mismas condiciones que las había tenido previamente Luis de Mesa, receptor de los bienes confiscados por la Inquisición en Sevilla ${ }^{99}$. ¿Tuvo algo que ver la dificultad para hacer efectivo el cobro de estos censos con la condición judeoconversa de los antiguos propietarios de estos inmuebles y la aplicación de los bienes confiscados por la Inquisición para financiar la guerra de Granada en $1487^{100}$ ?

En segundo lugar, la cesión de un juro 67.000 mrs con cargo a las rentas regias de Valdemoro e Illescas exigida como compensación por los problemas que había generado el cobro de los censos sevillanos cabe relacionarla con los intereses señoriales de Carrillo en el valle medio del Tajo. Gracias a su matrimonio en 1456 con Leonor de Toledo -hija del regidor toledano Pedro Suárez de Toledo y de Juana de Guzmán-, el guarda mayor pudo titularse señor de Pinto, villa situada a escasos $6 \mathrm{Km}$. de Valdemoro que había pertenecido a su suegro y heredó de su esposa ${ }^{101}$. Por lo tanto resultaba del todo coherente la petición de indemnizaciones económicas en este entorno geográfico en virtud de la capacidad logística de que podía disponer el beneficiario para hacer efectivo el cobro del juro, dentro de una estrategia que combinaba la presencia señorial en el territorio con la percepción de rentas líquidas con cargo al erario regio ${ }^{102}$.

Los intereses de Carrillo y Cárdenas volvieron a cruzarse una vez más en torno al cobro de este título de deuda, aunque no sea posible profundizar en las motivaciones que se escondían detrás de las transacciones que terminaron afectando al mismo. La cuenta de las alcabalas y tercias de las villas de Illescas, Valdemoro y Belinchón de 1497 registra el pago de estos $67.000 \mathrm{mrs}$ al Comendador Mayor de León. La cantidad correspondía a un juro de heredad concedido en Madrid el 10 de abril de 1495 a Gutierre de Cárdenas

\footnotetext{
98 AFRM, Caja 98, leg. 1, doc. 22. Sabemos que Luis de Mesa, receptor de los bienes confiscados a los conversos sevillanos por la Inquisición, dio a tributo una propiedad suya a Miguel de Montesdeoca, vecino de Lebrija, por cinco cahíces de pan anuales. Posteriormente, los reyes hicieron merced de todo ello a Alonso Carrillo de Castilla, y este posteriormente vendió los cinco cahíces de pan y otros bienes a Juan Gutiérrez Calderón, escribano de la ciudad. Gil Fernández, Los conversos y la Inquisición, p. 568. 99 AGS, RGS, marzo de 1485, f. 15.

${ }^{100}$ En octubre de 1487 el tesorero Luis de Medina recibía orden de los reyes de percibir la mitad del valor de los bienes señalados en los inventarios por los conversos reconciliados por la Inquisición, para su posterior aplicación a la financiación de la guerra de Granada. AGS, RGS, octubre de 1487, f. 205.

101 Franco Silva, "Señores y campesinos en tierras de Soria", pp. 522-524. Quijorna Rodríguez, "Mecanismos y estrategias", pp. 218-219.

102 En efecto, las previsiones de gasto situado con cargo a las alcabalas y tercias de Illescas, Valdemoro y Belinchón elaboradas por los contadores registran desde 1491 el pago de este juro a favor de Carrillo. Relación de cuenta de 1491 del recaudador mayor Rabí Mayr Melamed. AGS, EMR, leg. 50, f. 236. Ya en 1490 Alonso Carrillo percibía los $70.000 \mathrm{mrs}$ de su acostamiento con cargo a las alcabalas de Illescas, Valdemoro y Belinchón. AGS, EMR, leg, 48, f. 208; leg. 49, ff. 327-328.
} 
por "renunçiaçión que d'ellos le fizo el thesorero Ruy López de Toledo, que los antes tenía de Sus Altezas", según privilegio dado en Valladolid el 2 de marzo de 1495. La suma había sido previamente renunciada a favor del tesorero por su anterior beneficiario, a la sazón Alonso Carrillo, que los venía disfrutando según carta de privilegio dada en Córdoba el 16 de junio de 1491 "en pago de los mrs de renta que le ovieron a dar por los 16.000.000 mrs que dio a Sus Altezas, los quales le avía dado el dicho Comendador Mayor de la venta que le avían hecho de la villa de Maqueda, e Sus Altezas los tomaron para la guerra de los moros" ${ }^{103}$. Es evidente que los sucesivos traspasos de este juro ocultaban operaciones que vinculaban a Carrillo con estos agentes -ambos integrados en el equipo de gobierno de los reyes- en torno a intereses comunes, quizás derivados de deudas mutuas y/o con la Corona que los documentos consultados no explicitan.

Finalmente, como parte de la cancelación definitiva del préstamo, el finiquito dado por Carrillo en abril de 1491 daba fe del pago de 1.000.000 mrs con cargo a los recursos de la Real Hacienda, hecho efectivo en dos anualidades (1488 y 1489) ${ }^{104}$. A esta cuantía se sumaban los $400.000 \mathrm{mrs}$ en dinero líquido reconocidos en el último acuerdo renegociado con los reyes. Fueron pagados al guarda mayor con cargo a los recursos que gestionaban en 1491 los receptores y pagadores generales de las rentas ordinarias del reino Rabí Mayr Melamed y Luis de Alcalá, como compensación por los 500 vasallos y 300.000 mrs de renta "que se quedavan de conplir con él”, según figura en la cuenta que rindieron ante los oficiales de los reyes ${ }^{105}$. Todavía, según declaraba Carrillo en su carta de finiquito de 1491, los monarcas le habrían otorgado como compensación por su préstamo otras mercedes -quizás en alusión a las tenencias de Lebrija y Alcalá de Guadaíra, y a la veinticuatría de Sevilla- "por que yo sea e quede más satisfecho e remunerado de los dichos diez e seys quentos de maravedíes e de los dichos mill vasallos e seysçientas mill maravedíes de renta que por ellos me avían de dar" ${ }^{106}$.

\section{5. Últimas operaciones y finiquito del préstamo}

Al fin, entre fines de marzo y comienzos de abril de 1491, una vez cumplidas todas las cláusulas, la operación de amortización del préstamo de Carrillo concluyó tras ocho años de continuas renegociaciones. No obstante, todavía fue necesario sortear algunos problemas. El 3 de febrero de 1491 los reyes asignaban plazo de tres días, desde la recepción de su carta, a Alonso Carrillo para que diese su carta de seguro al concejo de Caracena y su tierra, ante las quejas presentadas ante los monarcas por los "agravios y sinrazones" cometidos por el guarda mayor, síntoma de su oposición, o al menos reticencia, a aceptarle como señor. En caso de negativa, los reyes darían su propia carta de seguro a la villa ${ }^{107}$. Solventada esta dificultad, el 26 de marzo, los reyes expedían

\footnotetext{
103 AGS, CMC, $1^{a}$ ép., leg. 164, sin f.

104 AFRM, Caja 98, leg. 1, doc. 22.

105 LAdero QuesadA, "La receptoría y pagaduría”, p. 474.

106 AFRM, Caja 98, leg. 1, doc. 22.

107 AGS, RGS, febrero de 1491, f. 300.
} 
finalmente en Sevilla su privilegio concediendo a Carrillo la jurisdicción de Caracena y su tierra con Inés, además de sus rentas señoriales ${ }^{108}$. Dos días antes, el 24 de abril, habían otorgado privilegio por el juro de heredad de $114.500 \mathrm{mrs}$ situados sobre sus alcabalas, además de las tercias reales cobradas en este territorio ${ }^{109}$.

Para concluir con lo acordado, el mismo 26 de abril los reyes expedían otros dos documentos solicitados por Carrillo como seguridad para la ejecución efectiva de ambos privilegios. En el primero, los monarcas garantizaban que, en cumplimiento de la "capitulaçión e asiento" por el cual habían cedido estas localidades y sus rentas como parte del pago por los 500 vasallos y 300.000 mrs concertado, en caso de que la villa y fortaleza de Caracena fuese tomada "agora o en algund tienpo" por Martín de Tovar, por sus hijos o por otra persona "a su causa" se comprometían a prestar todo su favor y ayuda a Alonso Carrillo para recobrarla, tomándola bajo su guarda, amparo, seguro y "defendimiento real". Todo ello podría ser pregonado a instancias de Carrillo o de los reyes allí donde fuese requerido ${ }^{110}$. En la segunda carta, dirigida al guarda mayor y con un contenido semejante al de la merced de Caracena e Inés, los monarcas reiteraban las garantías, comprometiéndose a hacer "çiertas e sanas" las mercedes y, en caso de incumplimiento, a pagar a Carrillo el doble de su valor o "la parte que d'ello vos fuere quitado", además de las costas y daños ocasionados ${ }^{111}$.

Con ello se daba cumplimiento a todos los capítulos negociados para amortizar el préstamo. Solo restaba que Carrillo expidiese su carta de finiquito a favor de los monarcas, cosa que hizo en Sevilla el 7 de abril de $1491^{112}$. En ella dejaba constancia de los diferentes acuerdos suscritos y renegociados con los reyes desde 1483, de la ejecución de todas las cláusulas y pagos, y de la expedición de los correspondientes privilegios referidos a aquellas compensaciones que así lo exigían. El documento constituía una garantía para la Corona, dentro del mismo juego de reciprocidades y seguridades mutuas del que participaba la documentación expedida a favor de Carrillo, pero también para el

\footnotetext{
${ }^{108}$ Los reyes señalaban que "queriendo conplir e cunpliendo con vos el dicho Alfón Carrillo lo que asy mandamos asentar e capitular en lo que toca e atañe a la dicha villa e lugares e rentas e cosas suso dichas pertenesçientes al señorío d'ellas por la presente vos hazemos merçed e damos a conplimiento de pago como dicho es, para vos e para vuestros herederos e subçesores después de vos, e para aquel o aquellos que de vos o d'ellos ovieren cabsa, e para quien vos quisiéredes e por bien toviéredes, de juro de heredad para sienpre jamás, la dicha villa de Caraçena e su fortaleza e logares de su tierra e término e jurediçión, e el dicho logar de Hynés con su torre e tierra e término e jurediçión, para que de aquí adelante la dicha villa e su fortaleza e lugares e términos e jurediçiones e con las otras rentas e pechos e derechos e martiniegas e yantares e escrivanías e portadgos e molinos e huertas e casas e tierras e heredamientos e otras cosas pertenesçientes al señorío de la dicha villa e su tierra e aldeas e lugar de Hynés e de cada una d'ellas" fueran poseídas por el guarda mayor. AGS, RGS, marzo de 1491, f. 4. El contenido de la carta es muy semejante, al referirse al complejo proceso de amortización del préstamo, a la carta de finiquito por la redención del préstamo expedida por Carrillo a favor de los reyes en Sevilla el 7 de abril siguiente.

109 AHNob, Frías, C. 1715, doc. 1.

110 AGS, RGS, marzo de 1491, f. 1.

111 AGS, RGS, marzo de 1491, f. 2.

112 La carta de finiquito de Carrillo, rubricada de su mano, fue expedida por el escribano de cámara de los reyes Juan de la Fuente ante Juan Velázquez Guillén, vecino de Sevilla, Miguel de Solana, alcaide y criado de Carrillo y Diego Gaytán, igualmente criado del guarda mayor.
} 
Comendador Mayor de León como parte implicada. De ahí que Gutierre de Cárdenas fuese el encargado, en calidad de contador mayor, pero también de intermediario en el pago inicial del préstamo, de custodiar el original del finiquito, conservado en su archivo. Su traslado también quedaría asentado, tanto en los "libros de las merçedes de juro de heredad" de los reyes, de lo que dieron fe con sus firmas algunos oficiales que trabajaban al servicio de los contadores -a saber Francisco González [de Sevilla], lugarteniente de Cárdenas, Fernán Gómez [de Écija], lugarteniente del contador mayor Juan Chacón ${ }^{113}$, Cristóbal Dávila y Villalobos-, como en los libros de las cuentas, de lo que dieron fe Juan Díaz de Alcocer y Alonso Ruiz ${ }^{114}$.

\section{Conclusión}

La compra de Maqueda por Cárdenas en 1483 y el préstamo de Carrillo a los reyes constituyen una buena muestra de dinámicas de negociación extensibles seguramente a otros procesos político-hacendísticos desarrollados en la Castilla de fines del siglo XV, de los cuales no han quedado sin embargo testimonios tan completos que permitan verificar desde la negociación inicial del empréstito, pasando por su pago efectivo y el camino seguido por el dinero líquido a través de las transferencias realizadas por los distintos intermediarios, hasta llegar a la renegociación de las condiciones de amortización y la cancelación final. El registro escrito de este tipo de procesos es particularmente expresivo del alcance de una cultura político-hacendística de la que participaban todas las partes implicadas y del nivel de "alfabetización" en la materia exhibido por algunos nobles con capacidad para asimilar y participar de fórmulas de financiación novedosas desde la perspectiva del momento, como también lo es la continua exigencia de garantías y seguridades jurídicas recíprocas. Al cabo, las estrategias seguidas y las fórmulas de cooperación articuladas en función de los intereses de cada parte implicada -en el caso analizado, la Corona, Gutierre de Cárdenas y Alonso Carrillo- permitían a todos los intervinientes maximizar sus beneficios en la medida en que existía una interdependencia entre todos ellos dentro de un sistema de relaciones complejo que no solo funcionaba mediante esquemas de dominación vertical.

Ciertamente, en este contexto, y una vez pacificado el reino tras la firma de la paz con Portugal y la puesta en escena de los nuevos planteamientos de la monarquía en las Cortes de Toledo de 1480, la participación en la guerra de conquista de Granada y en su financiación, como proyecto político con capacidad para cohesionar bajo la autoridad de los monarcas a diferentes instancias de poder, pudo convertirse en uno de los motores de la política de pactos y elaboración de consensos políticos, especialmente con los grandes nobles. Ello se hizo especialmente patente en los primeros compases de la contienda, cuando los reyes recurrieron a la toma de grandes cantidades en prés-

\footnotetext{
113 La adscripción de estos dos oficiales a los contadores mayores señalados en Gálvez GAMBERo, "Oficiales de la Contaduría Mayor de Hacienda, p. 304.

114 AFRM, Caja 98, leg. 1, doc. 22.
} 
tamo, sobre todo de miembros de la alta nobleza, posteriormente moduladas hacia una obtención de recursos mucho más diversificada, aunque las dinámicas de negociación continuaron operativas hasta el final de la guerra, y de nuevo se prolongaron durante los años de las guerras contra Francia marcando la pauta para actuaciones futuras ${ }^{115}$.

En este sentido, el préstamo de Alonso Carrillo, que permitió financiar un $25 \%$ de la tesorería de Ruy López de Toledo en 1483, suponía para la Corona articular nuevas estrategias de obtención de capitales derivados de la venta de jurisdicciones, con la particularidad de que el mecanismo escondía en realidad un sistema de capitalización de empréstitos muy cuantiosos en el que el nuevo titular de la jurisdicción, previamente interesado en obtenerla, lograba un beneficio en la medida en que alcanzaba la condición señorial deseada. Por su parte, el vendedor diversificaba las fuentes de su poder al conseguir, además de vasallos en áreas en las que buscaba consolidar su proyección señorial, la capacidad para cobrar rentas regias en forma de juro en otros espacios donde deseaba desarrollar o consolidar bases de poder, vendidas por la Corona como parte del procedimiento de amortización, en lo que suponía un ensayo que marcaba un nuevo hito en el camino hacia la creación de fórmulas de "deuda pública", pronto implantadas en Castilla, como los juros "de prestidos" o "al quitar".

De esta forma, con la compra de Maqueda, convertida más adelante en cabeza del Ducado que ostentaría, Cárdenas consolidaba un poder señorial en el valle medio del Tajo unido a las villas de Torrijos y Alcabón que había comprado del cabildo de Toledo mediante un procedimiento similar, gracias a su función como mediador en la búsqueda de recursos para la contienda y en pago por los especiales servicios que prestaba a los reyes. Por su parte, a partir de su sustanciosa aportación económica, el guarda mayor Alonso Carrillo podría exhibir su fidelidad a la monarquía de Isabel y Fernando, contra la que su linaje había combatido, mostrando el compromiso renovado de los CarrilloAcuña con los reyes, pero sobre todo lograba nuevas ventajas políticas y económicas condicionadas por la continua renegociación de las cláusulas de amortización del préstamo observada a partir de 1485 .

Estas ventajas pasaban por diversificar el alcance territorial de los beneficios obtenidos en tres áreas (Sevilla, el valle medio del Tajo y la frontera con Aragón), que combinaban el tradicional recurso a la obtención de vasallos como fuente de poder, con el más novedoso de lograr, a partir del servicio económico prestado, una participación creciente en el cobro de rentas, bien de titularidad regia en forma de juros de heredad, bien en forma de censos sobre bienes inmuebles. En este sentido, y pese a su gran complejidad, sería interesante seguir profundizando en el conocimiento de procesos similares para valorar el alcance y trasfondo de estas nuevas fórmulas de financiación como germen de dinámicas de pacto y participación en el sistema político.

\footnotetext{
115 Sobre los préstamos concertados a partir de 1495 ver LADERo QueSADA, Ejércitos y armadas, pp. 398 LAdero Quesada, Hernando de Zafra, pp. 58-61. Andrés Díaz, El último decenio del reinado de Isabel I, pp. 61-62.
} 


\section{Bibliografía citada}

Alós Ferrer, Carlos, "Teoría de juegos e historia económica: Una simbiosis necesaria”, ICE: Revista de economía, 812 (2004), pp. 27-34.

ANDRÉs DíAz, Rosana de, El último decenio del reinado de Isabel I a través de la tesorería de Alonso de Morales (1405-1504), Universidad de Valladolid, Valladolid, 2004. Ayala Martínez, Carlos de, "La escisión de los santiaguistas portugueses: algunas notas sobre los establecimientos de 1327", Historia. Instituciones. Documentos, 24 (1997), pp. 53-70.

Cañas Gálvez, Francisco de Paula, "Fray Hernando de Talavera: mediación económica y comunicación política en la Guerra de Granada (1491-1492)", Revista de Historia Militar, № Extra 1 (2018), pp. 175-196.

Castillo Pintado, Álvaro, "Los juros de Castilla. Apogeo y fin de un instrumento de crédito", Hispania, 89 (1963), pp. 43-70.

Castro de Castro, Manuel, "El Comendador Mayor Gutierre de Cárdenas compra las villas de Torrijos y Alcabón”, Anales Toledanos, 34 (1997), pp. 103-150.

CostA, Leonor Freire, "O espaço económico", en Luis Adão de Fonseca (coord.), Entre Portugal e a Galiza (sécs. XI a XVII). Un olhar peninsular sobre uma região histórica, CEPESE-Fronteira do Caos, Oporto, 2014, pp. 143-153.

DíAz IBÁÑEZ, Jorge, “El arzobispo Alfonso Carrillo de Acuña (1412-1482). Una revisión historiográfica, Medievalismo, 25 (2015), pp. 135-196.

Espinar Moreno, Manuel, Noticias sobre la Historia de Elche II. Don Gutierre de Cárdenas y herederos, señores de Elche, Crevillente y Aspe, Libros EPCCM, Granada, 2019. Espinar Moreno, Manuel, Testamento de Don Gutierre de Cárdenas y doña Teresa Enríquez, Libros EPCCM, Granada, 2019.

Francisco Olmos, José María de, "La evolución de los cambios monetarios en el reinado de Isabel la Católica según las cuentas del tesorero Gonzalo de Baeza (1477-1504)", En la España Medieval, 21 (1998), pp. 115-142.

Franco Silva, Alfonso, La fortuna y el poder. Estudios sobre las bases económicas de la aristocracia castellana (siglos XIV-XV), Servicio Publicaciones de la Universidad de Cádiz, Cádiz, 1996.

Gálvez Gambero, Federico, Endeudamiento y financiación de la Corona de Castilla en época Trastámara (ca. 1387-1504), Universidad de Málaga, Málaga, 2019. Tesis doctoral inédita.

Gálvez Gambero, Federico, “Oficiales de la Contaduría Mayor de Hacienda en tiempos de los Reyes Católicos (1474-1516)", Edad Media. Revista de Historia, 20 (2019), pp. 281-312.

Gálvez Gambero, Federico, "Reforma y consolidación de un activo financiero. Los «juros al quitar» en la «tesorería de lo extraordinario» de Juan y Alonso de Morales (1495-1504)", En la España medieval, 38 (2015), pp. 99-134. 
García FernándeZ, Manuel, "La documentación medieval del Archivo Francisco Rodríguez Marín en la Biblioteca General del Consejo Superior de Investigaciones Científicas de Madrid", Historia. Instituciones. Documento, 36 (2009), pp. 183-198.

García Fitz, Francisco, El castillo de Alcalá de Guadaíra (Sevilla). Estudio y fuentes documentales, Ayuntamiento de Sevilla-Instituto de la Cultura y las Artes, Sevilla, 2008. GiL Fernández, Juan, Los conversos y la Inquisición sevillana: el distrito y sus hombres, Universidad de Sevilla, Sevilla, 2003.

Hernández, Francisco J., Los cartularios de Toledo. Catálogo documental, Fundación Ramón Areces, Madrid, 1996.

Kirschberg SChenck, Deborah, Catálogo de los papeles del Mayordomazgo del siglo XV. VII (1489-1504), Ayuntamiento de Sevilla-Instituto de la Cultura de las Artes de Sevilla, Sevilla, 2013.

Kirschberg Schenck, Deborah, Catálogo de los papeles del Mayordomazgo del siglo XV. VI (1475-1488), Ayuntamiento de Sevilla-Instituto de la Cultura de las Artes de Sevilla, Sevilla, 2013.

Ladero Quesada, Miguel Ángel, Hernando de Zafra, secretario de los Reyes Católicos, Dykinson, Madrid, 2018.

Ladero Quesada, Miguel Ángel, Ejércitos y armadas de los Reyes Católicos. Nápoles y El Rosellón (1494-1504), Real Academia de la Historia, Madrid, 2010.

Ladero Quesada, Miguel Ángel, La Hacienda Real de Castilla, 1369-1504. Estudios y Documentos, Real Academia de la Historia, Madrid, 2009, pp. 226 y 338.

LADERo Quesada, Miguel Ángel, "Fray Hernando de Talavera en 1492: de la corte a la misión”, Chronica nova, 34 (2008), pp. 249-275.

LAdERo Quesada, Miguel Ángel, Castilla y la conquista del reino de Granada, Diputación Provincial de Granada, Granada, 1987.

Marcos Martín, Alberto, "Sobre desmembraciones, incorporaciones y ventas de señoríos eclesiásticos y de Órdenes Militares en Castilla durante el siglo XVI", en Salustiano de Dios, Javier Infante, Ricargo Robledo y Eugenia Torijano (eds.), Historia de la propiedad y de la expropiación, Universidad de Salamanca, Salamanca, 2012, pp. 51-82. Marcos Martín, Alberto, "«España en almoneda»: enajenaciones por el precio de alcabalas y tercias en el siglo XVI", en Luis Antonio Ribot García y Ernest Belenguer Cebrià (coords.), Las sociedades ibéricas y el mar a finales del siglo XVI. Vol. 4. La corona de Castilla, Sociedad Estatal Lisboa '98, Madrid, 1998, pp. 25-65.

Morales MuÑz, María Dolores Carmen, Alfonso de Ávila, rey de Castilla, Diputación Provincial de Ávila-Institución Gran Duque de Alba, Ávila, 1988.

Ortego Rico, Pablo, "Castilla, la Corona de Aragón y el Papado: relaciones financieras en torno a la cruzada y décima durante la guerra de Granada (1484-1492)", eHumanista: Journal of Iberian Studies, 43 (2019), pp. 199-248. 
Ortego Rico, Pablo, “La financiación de las Guardas Reales durante el reinado de los Reyes Católicos: crédito y finanzas a través de la actividad del tesorero Ruy López de Toledo (1480-1496)", en Enrique Martínez Ruiz, Jesús Cantera Montenegro, Magdalena de Pazzis Pi Corrales (eds.), La organización de los ejércitos, Cátedra Extraordinaria Complutense de Historia Militar, Madrid, 2016, vol. I, pp. 428-473.

Ortego Rico, Pablo, "Las riquezas de la Iglesia al servicio del poder monárquico: los empréstitos eclesiásticos en la Castilla del siglo XV", En la España medieval, 35 (2012), pp. 145-176.

Peinado Santaella, Rafael Gerardo, "Consejos que dio el fraile Sanzones a la reina Isabel I sobre cómo financiar la guerra de Granada (¿1482?)”, Revista del Centro de Estudios Históricos de Granada y su Reino, 27 (2015), pp. 197-203.

Porras Arboledas, Pedro Andrés, "El secretario real Francisco Ramírez de Madrid: Apuntes para una biografía”, Espacio, Tiempo y Forma. Serie III. Historia medieval, 8 (1995), pp. 169-182.

QuiJorna Rodríguez, Ana, "Mecanismos y estrategias de promoción, ascenso y consolidación de los Carrillo de Toledo, señores de Caracena y Pinto", Historia y Genealogía, 2 (2012), pp. 215-237.

Quintanilla Raso, María Concepción y BlázQuez Mayoral, Fernando, La forja de una casa nobiliaria bajo la monarquía de los Reyes Católico: la casa ducal de Maqueda, Sociedad Española de Estudios Medievales, Murcia, 2017.

RÁBAde Obradó, María del Pilar, "El doctor Juan Díaz de Alcocer: Apuntes biográficos de un servidor de los Reyes Católicos", Espacio, Tiempo y Forma. Serie III. Historia medieval, 3 (1990), pp. 259-288.

Rivera Recio, Juan Francisco, Los arzobispos de Toledo en la Baja Edad Media: siglos XII y XV, Diputación Provincial, Toledo, 1969, pp. 119-122.

SÁnchez-Cuenca, Ignacio, Teoría de juegos, Centro de Investigaciones Sociológicas, Madrid, 2009, $2^{\mathrm{a}}$ ed.

TeixeIra de Aragão, Augusto Carlos, Descripção geral e historica das moedas cunhadas em nome dos reis, regentes e governadores de Portugal, Imprenta Nacional, Lisboa 1875, vol. I.

Torre y del Cerro, Antonio de la, Torre, Francisco de la, Cuentas de Gonzalo de Baeza, tesorero de Isabel la Católica, Consejo Superior de Investigaciones Científicas, Patronato Marcelino Menéndez Pelayo, Madrid, 1955, 2 vols.

Villalba Ruiz de Toledo, Francisco Javier, "Reajustes de señoríos en el siglo XV: el trueque de Jadraque por Maqueda", Homenaje a Juan Torres Fontes. Vol. II, Secretariado de Publicaciones. Universidad de Murcia, Murcia, 1987, pp. 1.763-1.779.

Villalba Ruiz de Toledo, Francisco Javier, El cardenal Mendoza (1428-1495), Rialp, Madrid, 1988. 


\section{Apéndice documental}

\section{Documento I}

\section{3, febrero 21. Madrid}

Escritura notarial por la cual Alfonso Carrillo de Acuña reconoce darse por satisfecho del pago de los 17.150 .000 mrs realizado por el Comendador Mayor de León Gutierre de Cárdenas por la venta de Maqueda efectuada el 3 de febrero de 1483, pese a que la cantidad entregada por este último en piezas de oro y plata quedó en poder de diversas personas habida cuenta de que la suma ascendía a una cuantía muy elevada.

A. Consejo Superior de Investigaciones Científicas, Centro de Ciencias Humanas y Sociales, Biblioteca Tomás Navarro Tomás, Fondo “Archivo Francisco Rodríguez Marín”, Caja 98, leg. 1, doc. 14 (a). Original en papel y copia autorizada en 1728

B. Reg. M. García Fernández, "La documentación medieval del «Archivo Francisco Rodríguez Marín» en la Biblioteca General del Consejo Superior de Investigaciones Científicas de Madrid”, Historia. Instituciones. Documentos, 36 (2009), p. 192

«A todos los que la presente escriptura vieren como yo Alfonso Carrillo de Cuña, guarda mayor del rey e de la reyna, nuestros señores, otorgo e conozco que por razón que yo vendí a vos el magnífico señor don Gutierre de Cárdenas comendador mayor de León, contador mayor del rey e de la reyna, nuestros señores, la villa de Maqueda con su fortaleza e vasallos e tierra e términos e lugares d'ella con todo su señorío e juridiçión çevil e criminal alta e baxa e mero misto ynperio y con todas las rentas e pechos e derechos e tributos e escrivanías e martiniega e yantares e con todas las otras heredades e casas e heredamientos e prados e pastos e dehesas e montes e con todas las otras cosas anexas e perteneçientes al señorío de la dicha villa por preçio e contía de diez e syete quentos e çiento e çinquenta mill mrs que yo reçebí de vos el dicho señor comendador mayor, e me otorgo por contento e pagado d'ellos a toda mi guisa e voluntad segunt que más largamente pasó en la dicha venta y la yo otorgué ante Diego Rodríguez e Ruy Fernández, escrivanos públicos del número d'esta villa de Madrit ante quien esta carta se otorga a tres días d'este mes de febrero d'este año de mill e quatroçientos e ochenta e tres años, la qual dicha venta está firmada de mi nonbre, los quales dichos diez e syete quentos e çiento e çinquenta mill mrs los yo reçebí aquí en esta villa de Madrid e me apoderé d'ellos a toda mi voluntad al tienpo que asy otorgué la dicha venta, e por ser la suma de los dichos maravedíes tan grande e de tan grande contía no ove lugar en manera de los poner en otro cabo, e los dexé aquí de mi mano en poder de algunas personas que los toviesen por mí de mi mano e poder que de mí los reçebieron, e por que a la sazón y tiempo que yo asy otorgué la dicha venta e reçebí la dicha paga de los 
dichos diez e siete quentos e çiento e çinquenta mill maravedíes en la manera que dicha es, los dichos escrivanos e testigos de la dicha escriptura de venta non vieron fazer realmente la paga d'ellos segunt que en la verdad avía seydo e lo yo avía resçebido, por la dificultad de la grant suma de los dichos maravedíes del dicho preçio, e los yo dexé en poder de las dichas personas como dicho es, e por que los yo reçebí e otros en mi nombre, e por los aver res//çebido yo me dí e otorgué por contento e pagado como en la dicha escriptura de venta se contiene, y como quiera que aquello ansy pasó en realidad de verdad, pero por que aquello pueda paresçer más real e abiertamente para agora e para sienpre jamás ansy para toda entera verificaçión, declaraçión e manifestaçión de la dicha escriptura de venta e paga de que en ella se faze mençión e para mayor guarda e conservaçión del derecho de vos, el dicho señor comendador mayor, por esta escriptura otorgo e conosco que los dichos diez e siete quentos e çiento e çinquenta mill mrs yo los reçebí e agora resçibo en las monedas de oro de castellanos e ducados e doblas e florines e reales e cadenas de oro e pieças de plata apreçiadas en su valor en que todo ello montó los dichos diez e syete quentos e çiento e çinquenta mill maravedíes, de lo qual fago muestra e manifestaçión que lo tengo e estoy apoderado d'ello segunt por ello paresçe e se muestra aquí de presente ante los dichos Ruy Fernandez e Diego Rodríguez, escrivanos públicos suso dichos, e ante los otros cavalleros e testigos que aquí están presentes e de yuso serán declarados por sus nonbres e otros muchos que no van declarados, los quales dichos diez e syete quentos e çiento e çinquenta mill mrs que yo asy reçeby al tienpo de la dicha venta e agora yo reçibo de vos el dicho señor comendador mayor en las contías de monedas e pieças de plata suso dichas otorgo e conosco que es el valor e el preçio de la dicha venta que yo otorgué e fize al dicho señor comendador mayor de la dicha villa de Maqueda que ha estado en mi poder e de las personas a quien yo lo dexé de mi mano, e me do por contento e pagado segunt que antes lo fize e otorgué por la dicha escriptura, e agora fago demostraçión e manifestaçión de la dicha paga de la qual me apodero e entrego real e actual e verdaderamente syn otra ficçión nin symulaçión como por ella se muestra y manifiesta en presençia de los dichos escrivanos e testigos que de yuso serán contenidos, a los quales requiero e ruego que lo den asy sygnado de sus signos dando entera e conplida fee como personas públicas al dicho señor comendador mayor como vieron realmente// la dicha paga en mi poder a toda mi guisa e voluntad e contentamiento en las monedas de oro e pieças de plata suso dichas, de lo qual ansy como pasa realmente otorgué esta escriptura ante los dichos escrivanos e testigos, la qual va firmada de mi nombre que fue fecha e otorgada en la dicha villa de Madrid a veynte e un días del mes de febrero año del nasçimiento del nuestro salvador Ihesu Christo de mill e quatroçientos e ochenta e tres años. Testigos rogados que fueron presentes que vieron aquí en este público ynstrumento firmar su nonbre al dicho señor Alfón Carrillo: el bachiller Pedro de la Torre, e Françisco Ramírez, secretario, e Gonçalo de Baeça, contador, e el liçençiado Andrés Calderón, del Consejo del rey e reyna, nuestros señores, e su alcalde en la su Casa e corte, e Pedro de Ávila, alcayde que 
fue de Puñoenrostro, e Sancho de la Plaçuela, fijo de Diego Rodríguez, escrivano público, e Gerónimo, fijo de Ruy Ferrández, escrivano público, e el doctor Juan Díaz de Alcoçer, contador mayor de cuentas e del Consejo de los dichos señores rey e reyna, e Rodrigo de Mercado, corregidor vezino de la villa de Medina del Canpo, e Vasco de Bivero, vezino de la çibdat de Salamanca, e Pedro de Baeça, alcayde d'Escalona, e Juan de Ulloa, vezino de la çibdat de Toro, e Alonso Ordóñez de Villaquirán, e Ferrando de Çafra e Ferrando de Guzmán, e Ferrando de Ruyseco, e Rodrigo de Castañeda, e Alonso de Ludueña, todos quatro escuderos del dicho señor Alfón Carrillo.

E yo Ruy Ferrández, escrivano público de los del número de la villa de Madrid e su tierra por el rey e la reyna nuestros señores fuy presente a todo lo que suso dicho es juntamente en uno con Diego Rodríguez, escrivano// público, e con los dichos testigos e a ruego e otorgamiento del dicho señor Alonso Carrillo que en mi presençia e del dicho Diego Rodríguez, escrivano, firmó su nonbre, e de los dichos testigos asy mesmo este público ynstrumento fize escrivir para el dicho señor comendador mayor fize escrivir [sic] e do fe como vy reçebir al dicho señor Alfón Carrillo los dichos diez e siete cuentos e çiento e çinquenta mill mrs en las monedas de oro e plata suso declaradas realmente e con efetto a todo su contentamiento e por ende fize aquí este mío signo (signo del escribano).

\section{Ruy Ferrández (rúbrica)}

E yo Diego Rodríguez, escrivano público de la dicha villa de Madrit e su tierra por el rey e la reyna, nuestros señores, fuy presente a lo que dicho es en uno con el dicho Ruy Ferrández, escrivano público, e con los dichos testigos e de ruego e otorgamiento del dicho señor Alfón Carrillo, que aquí fyrma su nonbre en mi presençia, este público ynstrumento fiz escrivir para el dicho señor comendador mayor, e do fe como vy reçebyr al dicho señor Alfón Carrillo los dichos diez e siete cuentos e çiento e çinquenta mill mrs en las monedas de oro e plata suso declaradas, e por ende fiz aquí este mi signo (signo del escrivano)»

\section{Alonso Carrillo (rúbrica)}

\section{Documento II}

\section{3, octubre, 10. Vitoria}

Carta de pago otorgada por fray Hernando de Talavera, confesor de la reina Isabel I de Castilla, y Prior del Monasterio de Santa María de Prado, a favor de Gutierre de Cárdenas, Comendador Mayor de León, de 16.000.000 maravedís que, 
por orden de los reyes, debía entregar a Alonso Carrillo de Acuña, por la venta de la villa de Maqueda. Estos maravedies fueron prestados por Alonso Carrillo a los Reyes Católicos para la guerra de Granada.

A. Consejo Superior de Investigaciones Científicas, Centro de Ciencias Humanas y Sociales, Biblioteca Tomás Navarro Tomás, Fondo "Archivo Francisco Rodríguez Marín", Caja 98, leg. 1, doc. 15. Original, en pergamino

B. Reg. M. García Fernández, "La documentación medieval del «Archivo Francisco Rodríguez Marín» en la Biblioteca General del Consejo Superior de Investigaciones Científicas de Madrid", Historia. Instituciones. Documentos, 36(2009), p. 192. Cit. M.C. Quintanilla Raso y F. Blázquez Mayoral, La forja de una casa nobiliaria bajo la monarquía de los Reyes Católicos: la casa ducal de Maqueda. Murcia, 2017, pp. 177-178.

«La carta de pago del Prior de Prado de los diez y seis cuentos de maravedíes que resçibió de la paga de Maqueda. 10 octubre 1483//

Yo, fray Hernando de Talavera, Prior del Monasterio de Santa María de Prado, confesor de la Reyna, nuestra señora, otorgo e conozco que resçebí de vos el señor don Gutierre de Cárdenas, comendador mayor de León, señor de las villas de Maqueda e Torrijos, e Elche e Crevillente, contador mayor del Rey e de la Reyna, nuestros señores, e del su Consejo, e de algunas persona por vuestro mandado, diez e seis quentos de maravedíes e çiertas pieças de oro y reales y cadenas y rieles de oro e plata labrada, blanca y dorada, en esta guisa:

Porque resçibí en la villa de Madrid en los meses de março e abril deste presente año de ochenta y tres años, lo siguiente:

Por quatorse mill e ochosçientos e quarenta e dos castellanos y medio, a preçio de quatroçientos e ochenta e çinco maravedíes cada vno, que monta siete cuentos e çiento y noventa e ocho mill e seisçientos e doze maravedíes vii qs c xc viii $U$ de xii

Por çinco mill y çinquenta e siete doblas castellanas, a preçio de trezientos y sesenta e çinco maravedíes cada una, que un cuento e ochoçientos e quarenta y çinco mill e ochoçientos y çinco maravedíes

I q decc $x l \vee U$ decc $v$ 
Por dos mill e quatroçientos e treynta y çinco florines de Aragón, a preçio de dozientos e sesenta e çinco maravedíes cada uno, que montan seisçientas e quarenta y cinco mill e dozientos y setenta y çinco maravedíes

Por tres mill y quatroçientos y dos ducados y cruzados a preçio de trezientos e setenta y çinco maravedíes cada vno, que montan un quento e dozientas y setenta y çincos mill e setesçientos y çinquenta maravedíes

Por quatroçientos e doze enriques viejos a preçio de quatroçientos y setenta e çinco maravedíes, que montan çiento noventa y çinco mill e seteçientos maravedíes

Por çiento y sesenta e quatro coronas a preçio de trezyentos y çinquenta e çinco maravedíes cada una, que montan çinquenta e ocho mill y dozientos y veynte maravedíes

Por dozientas veynte e siete doblas zeyenes a preçio de quatroçientos e quarenta maravedíes cada una, montan noventa y nueve mill e ochoçientos e ochenta maravedíes

Por dos nobles de Inglaterra en seteçientos y çinquenta maravedíes cada vuo, que montan mill y quinientos maravedíes

Por sesenta y un mill y seisçientos y sesenta y siete reales de plata a preçio de treynta y un maravedíes cada uno, montan un quento y nueveçientas e onze mill y seiscientos y setenta e siete maravedíes

Por tres cadenas y un riel de oro, que pesaron, pesadas con castellanos, seiscientos y ochenta y dos castellanos, de los quales descontaron Gonçalo López de la Fuente y Françisco de Illescas, que fueron juezes, diez castellanos y medio de menguas de ley y de la hechura. Asy que queda seisçientos y setenta y un castellanos y medio, que montan a preçio de quatroçientos y ochenta y çinco maravedíes cada uno trezientos y veinte e çinco mill e seisçientos e seteta e siete maravedíes e medio

$\operatorname{ccc}$ xx v U de 1 xx vii

\section{IUd}

Por otra cadena grande de oro fino en trezientas mill maravedíes, la qual es del rey nuestro señor, en las quales trezientas mill maravedíes la teníades empeñada vos el dicho señor comendador mayor// 
Por çiertas pieças de plata labrada y dorada, que pesaron trezientos e ochenta y siete marcos e dos onças e dos ochavas, que fueron tasados por los dichos Gonçalo López y Françisco de Illescas y por Françisco Cota y Fernando platero, a çiertos preçios cada marco, que montó todo un quento y çiento y setenta e un mill y tresientos y noventa y cinco maravedíes

I q c lxx IU $\operatorname{ccc} x c \mathrm{v}$

Por que recebí en la çibdad de Santo Domingo de la Calçada en el mes de mayo deste dicho año de Hernando Sedeño, vuestro camarero, quatroçientas y sesenta e un mill e quatro çientas y treynta y ocho maravedíes $\operatorname{ccc} 1 \mathrm{xv}$ IU $\operatorname{ccc} \mathrm{xxx}$ viii

Por que reçibió por my y en mi nombre Johan de la Torre, vezino de Carrión, en la çibdad de Córdova en el mes de agosto d'este dicho año, de Alfonso Vázquez, vuestro capellán, trezientas e diez mill maravedíes

$\operatorname{ccc} \times \mathrm{U}$

Por que reçibí en la ciudad de Vitoria, hoy de la fecha d'esta carta lo siguiente

Por un platel y dos escudillas y quatro cuchares de plata blanca, que pesó siete marcos y una onça y dos reales de plata, a preçio de dos mil y çinquenta maravedíes el marco montan quatorze mill y seisçientos e sesenta y ocho maravedíes

xiiii IU dc lx viii

Por noventa y dos águilas de oro de Siçilia a preçio de quatroçientos y çinco maravedíes cada una montan treynta y siete mill y dozientos e sesenta maravedíes Xxxv ii $U$ cc $1 \mathrm{x}$ Por quatroçientos e treynta y çinco ducados genougués e florentines e romanos, e úngaros y seneses y cruzados milaneses e napolitanos y de Ferrara que monta en ellos, a preçio de trezyentos e setenta y çinco maravedíes cada uno, çiento e sesenta e tres mill e çiento e veynte e çinco maravedíes

Por que monta e las dichas pieças de oro y plata y reales y cadenas y riel en la manera suso dicha los dichos diez e seis cuentos de maravedíes. E más de diez e seys mill e çiento ocho maravedíes que Gonçalo de Baeça e Francisco de Illescas juzgaron que se diesen a Gonçalo Fernández de Alcalá e Iohan de la Torre por las menguas que ovo en el dicho oro.

De lo qual todo me otorgo por bien contento y entrego e pagado a toda my voluntad por quanto lo recebí e pagó de vuestro poder al myo en el dicho oro, e plata y pieças de suso dichas. Lo qual recebí en nombre del rey e de la reyna, nuestros señores, por 
Alfonso Carrillo de Acuña que los prestó a Sus Altezas. E vos el dicho comendador mayor lo oviste de dar al dicho Alfonso Carrillo por la compra de la vuestra villa de Maqueda que d'él comprastes. E por quanto yo he dado otra carta de pago d'estos dichos diez e seys cuentos de maravedíes entiéndase que ella y esta es toda vna.

Fecha en la çibdad de Vitoria a diez días del mes de otubre, año del nasçimiento de nuestro Señor Ihesu Christo de mill e quatroçientos e ochenta y tres años.

$<$ Digo diez y seys quentos de maravedíes $>$.

Indigno Prior de Prado»

\section{Documento III}

\section{5, marzo 15. Écija}

Provisión de los reyes al Comendador Mayor de León Gutierre de Cárdenas en la que se le autoriza para hacer pleito-homenaje por la entrega de la tenencia de la fortaleza y alcázares de Carmona a Alonso Carrillo de Acuña, según había solicitado este último como seguridad en caso de incumplimiento de la capitulación acordada en Sevilla el 4 de febrero de 1485 con los monarcas. Dicho incumplimiento se refería a la cláusula relativa a la cesión de la fortaleza de Molina y Torre de Aragón por parte de Juan de Torres a Alonso Carrillo una vez transcurridos los seis meses de plazo habilitado para que los reyes hiciesen efectiva la entrega de mil vasallos y seiscientos mil maravedies a este último y cumpliesen los restantes compromisos acordados con él. En caso de que transcurrido dicho plazo, y ante el incumplimiento de lo comprometido por los reyes, Juan de Torres se negase a devolver la fortaleza de Molina y Torre de Aragón a Alonso Carrillo, este último recibiría de Gutierre de Cárdenas la fortaleza y alcázares de Carmona. Los reyes ordenan, igualmente a Cárdenas, dar a Alonso Carrillo su carta de seguridad sellada con el sello de sus armas de que cumplirá con lo ordenado, y levantan al Comendador Mayor de León cualquier pleito-homenaje, fe o seguridad que les pudiera haber hecho por la tenencia de la fortaleza y alcázares de Carmona.

A. AGS, RGS, marzo de 1485 , f. 28

B. Cit. M.C. Quintanilla Raso y F. Blázquez Mayoral, La forja de una casa nobiliaria bajo la monarquía de los Reyes Católicos: la casa ducal de Maqueda. Murcia, 2017, p. 179

«Don Fernando e doña Ysabel etc. a vos don Gutierre de Cárdenas, comendador mayor de León, nuestro contador mayor e del nuestro Consejo, salud e graçia.

Sepades que en çierta capitulaçión que por nuestro mandado se fizo con Alonso Carrillo d'Acuña, nuestro vasallo, en la çibdad de Sevilla a quatro dyas de febrero d'este presente año de la data d'esta nuestra carta se contyene e es concordado e asentado qu'el 
dicho Alonso Carrillo aya de entregar e entregue a Iohan de Torres, vezino de Soria, en nonbre de Sus Altezas, la villa de Molina e alcáçar e la Torre de Aragón que agora tyene el dicho Alonso Carrillo en prendas por los dichos mill vasallos e seysçientas mill maravedíes de renta dentro de quinze dyas primeros syguientes contados desd'el dya que le fuere notificado por parte de Sus Altezas de cómo fueron entregados por ante escrivanos públicos al dicho Alonso Carrillo, o a quien su poder tovo, la dicha villa e fortaleza de Caraçena con sus vasallos e logares de su tierra, e el dicho logar de Hynés con su torre e vasallos e con las rentas e pechos e derechos de los dichos logares, e las heredades que le han de ser dadas en la dicha çibdad de Sevilla e su arçobispado, asy por las dichas seysçientas mill mrs como por lo que ovo de aver en pago de los dichos çinquenta vasallos e de la renta que faltó en los dichos logares a conplimiento de las dichas trezientas mill mrs de renta sy lo tomare en las dichas heredades, e cómo le fue entregada la dicha fortaleza de Lebrixa e la casa e la casa que le han de dar en Sevilla, apoderando al dicho Iohan de Torres en lo alto e baxo de la dicha villa de Molina e alcáçar e torre de Aragón// a toda su voluntad para que lo tenga por tienpo de los dichos seys meses en que ha de ser pagado el dicho Alonso Carrillo en vasallos de los vasallos que le faltaren en la dicha Caraçena e su tierra, e en el dicho logar de Hynés, a cunplimiento de quatroçientos e çinquenta vasallos que ha de aver como dicho es, e le ha de ser dada e entregada la dicha sentençia que fuere dada contra el dicho Martín de Tovar e el dicho saneamiento del derecho que la dicha su muger tyene al dicho logar de Hinés [por] carta de Sus Altezas en que seguran e prometen que los dichos vasallos le serán çiertos e sanos en todo tienpo, e sy no le fueren dados dentro de los dichos seys meses los dichos vasallos que asy faltaren a cunplimiento de los dichos quatroçientos e çinquenta vasallos e la dicha sentençia e saneamiento del derecho de la muger del dicho Martín de Tovar al dicho lugar de Hinés e la dicha seguridad de Sus Altezas, en tal caso por qualquier d'estas que non le fuere dada nin entregada dentro de los dichos seys meses sea obligado el dicho Iohan de Torres de entregar al dicho Alonso Carrillo luego pasados los dichos seys meses la dicha villa de Molina e alcáçar e torre de Aragón apoderándole en lo alto e baxo d'ello a toda su voluntad, e que Sus Altezas le ayan de dar e den al dicho tienpo el corregimiento de la dicha villa de Molina e librarle çient mill mrs en cada un año con la tenençia de la dicha villa e alcáçares e torre de Aragón para que lo tenga todo por prendas e seguridad de los dichos vasallos que asy faltaren en la dicha Caraçena e Hynés a conplimiento de los dichos quatroçientos e çinquenta vasallos, e de la dicha sentençia que le ha de ser dada por donde son confiscados los dichos logares, e del dicho saneamiento del derecho de la muger del dicho Martín de Tovar al dicho logar de Hinés, e de la dicha seguridad de escriptura que Sus Altezas le han de dar como dicho es, e de qualquier cosa d'ello que non se oviere conplido con él segund el tenor e forma d'esta capitulaçión, de lo qual aya de fazer e faga el dicho Juan de Torres pleito omenaje en forma al dicho Alonso Carrillo al tienpo que por él le fuere entregada la dicha villa de Molina e alcáçar e torre de Aragón, e seyendo conplido por Sus Altezas con el dicho Alonso Carrillo sea obligado de tornar e restituyr la dicha villa de Molina e alcáçar e torre de Aragón e corregimiento a Sus Altezas, o a quien 
para ello su poder oviere, luego que el tal conplimiento fuere fecho, e faga d'ello pleito omenaje// en forma al tienpo que lo entregare el dicho Juan de Torres, e por quanto al tienpo que la dicha capitulaçión se fizo e asentó, el dicho Alonso Carrillo nos pydió que mandásemos a vos el dicho comendador mayor don Gutierre de Cárdenas que le asegurásedes e fiziésedes pleito omenaje que sy el dicho Iohan de Torres non conpliese con él en la entrega de la dicha villa e fortaleza de Molina e torre de Aragón segund era obligado por virtud del dicho capítulo e del pleito omenaje que sobre ello ha de fazer el dicho Iohan de Torres al tienpo que resçibió la dicha villa de Molina con la dicha fortaleza e torre de Aragón del dicho Alonso Carrillo que vos le entregaríades en tal caso los alcáçares e fortaleza de la villa de Carmona que por nuestro mandado tenéys en tenençia para que los toviese el dicho Alonso Carrillo fasta que nos con él oviésemos conplido todo lo contenido en el dicho capítulo $<$ o fasta que le fuese tornado e entregado el dicho alcáçar $>$ e por que nuestra merçed e voluntad es que asy se faga e cunpla por la presente vos mandamos a vos el dicho comendador mayor que vos como ome fijodalgo fagades seguridad de pleito omenaje en forma devida al dicho Alonso Carrillo que sy el dicho Iohan de Torres non le diere e entregare realmente e con efecto a él, o a quien su poder para ello oviere, la dicha fortaleza de Molina e torre de Aragón luego pasados los dichos seys meses contenidos en el dicho capítulo en el caso que nos no oviéremos conplido con lo que somos obligados de fazer e conplir con él, segund el tenor e forma del dicho capítulo, daréys e entregaréys al dicho Alonso Carrillo o a quien el dicho su poder oviere, luego pasado los dichos seys meses contenidos en el dicho capítulo, los dichos alcáçares e fortaleza de la dicha villa de Carmona, e entregaréys e faréys entregar e apoderadedes e faréys apoderar en lo alto e baxo d'ella, a toda su voluntad, para que lo tenga fasta que nos ayamos conplido con él todo lo contenido en el dicho capítulo suso encorporado e cada una cosa e parte d'ello $<_{0}$ fasta que le sea tornado e entregado el dicho alcáçar e torre>, que vos dándole e entregándole al dicho Alonso Carrillo, o a quien el dicho su poder oviere, los dichos alcáçares e fortaleza de la dicha villa de Carmona en la forma suso dicha, nos por la presente vos alçamos qualquier pleito omenaje, fee e seguridad que por ellos nos tengades fecho, e vos damos por libre e quito de todo ello para agora e para syenpre jamás, e vos mandamos que le dedes vuestra// carta firmada de vuestro nonbre e sellada con el sello de vuestras armas por que el dicho Alonso Carri[11]o sea más çierto e seguro que asy se fará e conplirá, e otrosy vos mandamos que fecho por vos el dicho pleito omenaje al dicho Alonso Carrillo le guardéys e cunpláys realmente e con efecto syn nos requerir nin consultar nin aver nuestra liçençia para ello ca nos, segund dicho es, vos alçamos el dicho pleito omenaje e fee e seguridad que por las dichas fortaleças e alcáçares de Carmona nos tengades fecho para que syn enbargo d'ello les deys e entreguéys al dicho Alonso Carrillo después de pasados los dichos seys meses sy durante aquellos non se oviere conplido con él todo lo suso dicho que asy somos obligados por virtud del dicho capítulo e el dicho Juan de Torres non oviere conplido con él de la forma e manera que dicha es, de lo qual mandamos dar esta nuestra carta firmada de nuestros nonbres e sellada con 
nuestro sello dada en la çibdad de Éçija a <quinze> días de março año del nasçimiento de nuestro señor Ihesu Christo de mill e quatroçientos e ochenta e çinco años.

Yo el rey. Yo la reyna. Yo Fernand Álvarez de Toledo, secretario del rey e de la reyna, nuestros señores, la fize escrivir por su mandado. Acordada y en forma. Rodericus doctor»».

\section{Documento IV}

\section{1, abril 7. Sevilla}

Carta de pago y finiquito original que otorgó Alonso Carrillo, señor de Caracena, en favor de los reyes, por los 16.000.000 mrs que había prestado para los gastos de la guerra de Granada de los 17.150.000 mrs que el Comendador Mayor de León Gutierre de Cárdenas le había dado por la compra de la villa de Maqueda.

A. Consejo Superior de Investigaciones Científicas, Centro de Ciencias Humanas y Sociales, Biblioteca Tomás Navarro Tomás, Fondo "Archivo Francisco Rodríguez Marín”, Caja 98, leg. 1, doc. 22. Original, en papel

B. Reg. M. García Fernández, "La documentación medieval del «Archivo Francisco Rodríguez Marín» en la Biblioteca General del Consejo Superior de Investigaciones Científicas de Madrid”, Historia. Instituciones. Documentos, 36 (2009), p. 193

«Sepan quantos esta carta de pago e fyn e quito vieren como yo, Alfón Carrillo de Castilla, señor de la villa de Caraçena, digo que por quanto yo ove vendido e vendí la villa de Maqueda con su tierra e fortaleza, e con las otras cosas al señorío d'ella pertenesçientes, a don Gutierre de Cárdenas, comendador mayor de León, señor de la dicha villa de Maqueda, por çierta quantía de maravedíes las quales el dicho comendador mayor me dio e pagó e yo resçebí e pasaron a mi parte e poder realmente e con efecto, y yo por servir a los muy altos e muy poderosos el rey e la reyna de Castilla, de León, de Aragón e de Seçilia etc., nuestros señores, para las nesçesydades que a la sazón les ocurrieron de cunplir para la guerra de los moros enemigos de nuestra Santa Fe Católica, les socorrí con diez e seys quentos de maravedíes de los maravedíes que así me dio e pagó el dicho comendador mayor, e Sus Altezas mandaron asentar e capitular comigo de me dar por los dichos diez e seys quentos de maravedíes mill vasallos en çiertos lugares de sus reynos e seysçientas mill maravedíes de renta que yo pudiera aver y conprar por los dichos diez e seys quentos de maravedíes a la sazón que ge los dí, e por seguridad que Sus Altezas mandarían cunplir e cunplirían comigo los dichos mill vasallos e seysçientas mill maravedíes de renta me mandaron dar y dieron en peños e en nombre de peños la villa de Molina con su fortaleza e con seysçientas mill mrs de renta que mandaron asentar e asentaron comigo de me dar en pago de los dichos diez 
e seys quentos de maravedíes, segund más largamente se contiene en las escripturas e capitulaçiones que sobr'ello pasaron.

Después de lo qual por algunas dificultades que ocurrieron en el cunplimiento de lo contenido en la dicha capitulaçión mandaron asentar e fue asentado comigo de mi consentimiento e voluntad que me oviesen de ser pagados los dichos mill vasallos e seysçientas mill maravedíes de renta en esta manera: que me oviesen de dar en pago de los quinientos vasallos d'ellos e de las trezientas mill maravedíes de renta heredades en Sevilla e su tierra e arçobispado que rentasen en renta e çenso perpetuo seysçientas mill maravedíes de renta en cada un año, e por los otros quinientos vasallos e trezientas mill maravedíes de renta restantes a cunplimiento de los dichos mill vasallos e seysçientas mill maravedíes de renta me oviesen de dar la dicha villa de Caraçena con su fortaleza e lugares e aldeas de su tierra e término e juridiçión, e el logar de Hinés con su torre e término e juridiçión, e trezientas mill maravedíes de renta, por virtud de lo qual me fueron dadas e entregadas en la dicha çibdad de Sevilla e su arçobispado las dichas seysçientas mill maravedíes de renta en heredamientos e çensos e tributos a mi contentamiento con los títulos e derechos que Sus Altezas tenían a ello, las quales dichas seysçientas mill maravedíes de renta yo resçebí.

E porque después algunos de los dichos çensos e tributos me salieron ynçiertos e asy mismo paresçió que me avían seydo cargados algunos d'ellos en más presçio de lo que comúnmente valían en la dicha çibdad de Sevilla fueron vistos e esaminados todos los contratos de los dichos çensos y los títulos d'ellos e el verdadero e justo valor que valían, y todo visto fue asentado comigo por mandado de Sus Altezas e de mi consentimiento que me oviesen de mandar dar e diesen por los dichos quinientos vasallos e trezientas mill maravedíes de renta quinientas e noventa e çinco mill mrs de tributos e çensos en la dicha çibdad de Sevilla e su tierra e más sesenta e syete mill mrs e de juro sytuados en çiertas rentas del lugar de Valdemoro e de la villa de Yliescas, e más que me fuesen librados e pagados quatroçientas mill mrs mrs en dineros, esto a conplimiento de pago de los dichos quinientos vasallos e trezientas mill maravedíes de renta, de guisa que restaron de cunplir comigo los otros dichos quinientos vasallos en la dicha villa de Caraçena e su tierra e lugar de Hinés, y las dichas trezientas mill maravedíes de renta, en cunplimiento de lo qual fueron contados los vasallos que avrá en la dicha villa de Caraçena e lugares de su tierra y en el dicho lugar de Hinés, e asy mismo se sopo e averiguó el valor de las rentas de la dicha villa e logares, asy las pertenesçientes al señorío d'ella como las terçias e alcavalas d'ellas pertenesçientes a Sus Altezas.

E fallose por Diego de Valladolid, posentador de Sus Altezas, e por Ferrando de Córdova, mi criado, que para ello de mi consentimiento fueron diputados, que avrá en la dicha villa de Caraçena e lugares de su tierra, e en el dicho lugar de Hinés, trezientos e setenta e syete vasallos e medio, de guisa que restaron para cunplimiento de los dichos quinientos vasallos çiento e veynte e dos vasallos e medio. E asy mismo se falló por los dichos diputados que valían las rentas e pechos e derechos e molinos e paso de ganados e huertas e casas e terradgos e las terçias de la dicha villa de Caraçena e Hinés e de los lugares de Madruédano e Santa María del Val 
e Adanta, que son aldeas de la dicha villa de Caraçena, asy de pan e vino e maravedíes como de ganados e otras cosas e todas las otras pertenesçientes al señorío de la dicha villa e logares en pan e dineros e otras cosas, reduzido todo a dineros, syn las alcavalas, çiento e syete mill e seysçientos e setenta e ocho mrs de renta en cada año, e en las alcavalas de la dicha villa de Caraçena e lugares de su tierra e del dicho lugar de Hinés çiento e quatorze mill e quinientos maravedíes que me fueron sytuados de juro de heredad, por manera que restaron para cunplimiento de las dichas trezientas mill mrs de renta setenta e syete mill e ochoçientos e veynte e dos maravedíes, por los quales fue asentado que me oviesen de mandar dar e diesen ochenta mill maravedíes de çensos e tributos que me fueron dados segund dicho es, con los quales dichos çiento e siete mill e seysçientos e setenta e ocho maravedíes de renta pertenesçientes al señorío de la dicha villa de Caraçena e su tierra e Hinés e terçias suso dichas, e con los dichos çiento e catorze mill e quinientos maravedíes de juro sytuados en las alcavalas de la dicha villa de Caraçena e su tierra e Hinés, e con los dichos ochenta mill maravedíes de tributo en la dicha çibdad de Sevilla e su tierra fueron a cunplimiento de pago de las dichas trezientas mil maravedíes de renta, quedaron por cunplir comigo los dichos çiento e veynte e dos vasallos e medio los quales fueron estimados a ocho mill maravedíes cada vasallo en que montaron nueveçientas e ochenta mill maravedíes por los quales// me fueron dados çient mill maravedíes de juro sytuados en las alcavalas de la villa de Alcalá de Guadayra que es en el partido de Xerez de la Frontera, e asy me fueron cunplidos e pagados los dichos quinientos vasallos e trezientas mill maravedíes de renta, allende de lo qual Sus Altezas me fizieron merçed de un quento de mrs librados en los años pasados de ochenta e ocho [e] ochenta e nueve, e los yo resçebí a entero conplimiento de pago de los dichos diez e seys quentos de maravedíes que Sus Altezas de mí resçibieron e de los dichos mill vasallos e seysçientas mill maravedíes de renta que por ellos me avían de dar segund que todo más largamente en las dichas capitulaçiones e escripturas que sobr'ello pasaron se contenía.

Las quales, e cada una d'ellas avidas aquí por espresadas, otorgo e conosco en la mejor forma e manera que puedo e de derecho devo, que resçebí e me fueron dados e entregados por mandado de los dichos rey e reyna, nuestros señores, las dichas seysçientas e setenta e çinco mill maravedíes de tributos e çensos perpetuos en heredamientos e casas e haziendas e bienes rayzes en la dicha çibdad de Sevilla e su arçobispado que los rentan e valen, e los yo tengo e poseo por virtud de una carta de Sus Altezas firmada de sus nonbres e sellada con su sello que me fue dada con las sentençias e condepnaçiones contra las personas cuyos fueron los dichos bienes rayzes e heredamientos de los dichos tributos por donde fueron confiscados e aplicados a la cámara e fisco de Sus Altezas e los contratos por donde son obligados a pagar los dichos tributos las personas que tienen los dichos heredamientos e bienes rayzes.

E asy mesmo resçebí los dichos sesenta e syete mill mrs de juro de heredad para syenpre jamás sytuados en las dichas rentas del lugar de Valdemoro e de la villa de Yliescas de los quales me fue dada carta de previllejo de Sus Altezas. 
E asy mesmo resçebí las dichas quatroçientas mill mrs en dineros contados que me fueron librados e pagados por mandado de Sus Altezas.

E asy mesmo resçebí la dicha mi villa de Caraçena con su fortaleza e lugares e vasallos d'ella e de su tierra e el dicho lugar de Hinés con sus términos e juridiçiones çevil e criminal alta e baxa e mero misto ynperio e rentas e pechos e derechos pertenesçientes al señorío d'ella, e por título d'ello me fue dada una su carta de merçed escripta en pergamino e firmada de sus nonbres e sellada con su sello, e carta exsecutoria de la sentençia que fue dada contra Martín de Tovar, que se solía llamar Juan de Tovar, cuya fue la dicha villa de Caraçena y su tierra y lugar de Hinés, por donde todos sus bienes fueron confiscados e aplicados a la cámara e fisco de Sus Altezas, e así mismo resçebí çiertas escripturas de çesiones e traspasaçiones que en Sus Altezas fizieron los fijos e fijas del dicho Martín de Tovar e de doña Leonor de Villena, su muger, de qualquier derecho que tenían e les pertenesçía al dicho lugar de Hinés por razón del dote e arras de la dicha su madre o en otra qualquier manera.

E asy mismo resçebí los dichos çiento e catorze mill e quinientos mrs de juro sytuados en las dichas alcavalas de la dicha villa de Caraçena y su tierra y lugar de Hinés e merçed de las dichas terçias, de lo qual me fue dada otra carta de previllejo de Sus Altezas.

E asy mismo resçebí los dichos çient mill mrs de juro sytuados en las dichas alcavalas de la dicha villa de Alcalá de Guadayra que es en el partido de Xerez de la Frontera de lo qual me fue dada carta de previllejo en forma.

E asy mesmo resçebí el dicho un quento de maravedíes de merçed en dineros contados que me fueron librados e pagados por mandado de Sus Altezas

E allende de todo lo que dicho es he resçebido otras merçedes de Sus Altezas que me han fecho por que yo sea e quede más satisfecho e remunerado de los dichos diez e seys quentos de maravedíes e de los dichos mill vasallos e seysçientas mill maravedíes de renta que por ellos me avían de dar segund dicho es.

De lo qual todo, e de cada cosa d'ello, e de los dichos títulos e previllejos e escripturas d'ello, me otorgo por bien contento e pagado e entregado a toda mi voluntad, e doy por libres e quitos a Sus Altezas e a sus bienes de los dichos diez e seys quentos de maravedíes e de los dichos mill vasallos e seysçientas mill maravedíes de renta que por ellos me avían de mandar dar, e de todas las otras cosas que por mandado de Sus Altezas comigo fueron capituladas e asentadas por manera que por yo aver dado como dí a Sus Altezas los dichos diez e seys quentos de maravedíes, por lo que por su mandado comigo fue asentado e capitulado, sobre esta razón no me queda acçión nin recurso alguno a Sus Altezas nin a la dicha villa de Molina e su fortaleza que me fue dada en peños, segund dicho es, nin a otra cosa alguna, agora nin en algund tienpo, e doy por ningunos e de ningund efecto e valor qualesquier capitulaçiones e asyentos e prometimientos e obligaçiones que sobre lo suso dicho fueron fechos por Sus Altezas, e por otros en su nonbre en qualquier manera, e otorgo e soy contento por esta presente carta que aunque en algund tienpo parescan las dichas capitulaçiones o asyentos que sobre esto pasaron, o alguna d'ellas o sus traslados sygnados, que non me puedan aprovechar yo nin mis 
herederos e subçesores, nin otro por mí nin por ellos, de las dichas capitulaçiones nin de cosa alguna de lo en ellas contenido, para poder demandar por virtud d'ellas cosa alguna de lo que asy me fue prometido, pues de todo ello soy contento e pagado segund dicho es, e en razón de la paga de todo lo suso dicho renunçio qualesquier leyes e fueros e derechos que en esto fablan, e asy mesmo renunçio// todas las otras leyes e fueros e derechos de que me pueda aprovehar, e la ley que diz que general renunçiaçión non vala, e porque esto sea firme e non venga en dubda otorgué esta carta de pago e fin e quito ant'el escrivano e testigos de yuso escriptos e por mayor firmeza la firmé de mi nonbre, que es fecha e otorgada en la çibdad de Sevilla a siete días del mes de abril año del nasçimiento de nuestro señor Ihesu Christo de mill e quatroçientos e noventa e un años.

Alonso Carryllo (rúbrica)

Testigos que fueron presentes al otorgamiento d'esta carta de pago e fin e quito e vieron firmar aquí su nonbre al dicho Alfón Carrillo. Juan Velázquez Guillén, vezino de la çibdad de Sevilla, e Miguel de Solana, alcayde e criado del dicho Alfón Carrillo e Diego Gaytán, su criado, para esto llamados e rogados.

E yo Iohan de la Fuente, escrivano de cámara del rey e de la reyna, nuestros señores, e su notario público en la su corte e en todos sus regnos e señoríos, fuy presente al otorgamiento d'esta carta de pago e fin e quito e vi firmar aquí este su nonbre al dicho Alonso Carrillo en uno con los dichos testigos e de su ruego e otorgamiento la fize escrivir, e por ende en testimonio de verdad fize aquí este mío sygno (signo del escribano). Iohan de la Fuente (rúbrica)

Asentose esta carta de fin e quito que Alonso Carrillo de Castilla en este fin e quito contenido dio e otorgó al rey e a la reyna, nuestros señores, segund que en ella se contiene en los sus libros de las merçedes de juro de heredad señaladamente al pie de los previllejos de los çiento e setenta e siete mill maravedíes que al dicho Alonso Carrillo fueron dados de juro de heredad de que en este fin e quito faze minçión que está asentado en los dichos libros.

Françisco Gonçález (rúbrica)

Fernán Gómez (rúbrica)

(Ilegible) de Villalobos (rúbrica)

Christóval Dávila (rúbrica)//

Asentose esta carta de fin e quito qu'el dicho Alonso Carrillo en él contenido dio al rey e a la reyna nuestros señores en los libros de las cuentas de Sus Altezas que tienen los sus contadores mayores de las sus cuentas

Iohanes doctor (rúbrica)

Alonso Ruiz (rúbrica)» 
